NBER WORKING PAPER SERIES

\title{
EXPORTS AND MANUFACTURING PRODUCTIVITY IN EAST ASIA: A COMPARATIVE ANALYSIS WITH FIRM-LEVEL DATA
}

\author{
Mary Hallward-Driemeier \\ Giuseppe Iarossi \\ Kenneth L. Sokoloff \\ Working Paper 8894 \\ http://www.nber.org/papers/w8894 \\ NATIONAL BUREAU OF ECONOMIC RESEARCH \\ 1050 Massachusetts Avenue \\ Cambridge, MA 02138 \\ April 2002
}

\begin{abstract}
We wish to thank Dee Sutthiphisal, Dennis Tao and Hairong Yu for their tremendous assistance in organizing the database, To Nhu Dao for excellent research assistance, and Francis Colaco, David Dollar, and Dominique DworFrecaut, whose support and guidance were instrumental to the survey initiative. We also benfited from valuable discussions with Bee Yan Aw, Andrew Bernard, Stanley Engerman, Chang-Tai Hsieh, Zorina Khan, Edward Leamer, Ricardo Lopez, Rob Porter, and participants in the Dartmouth College Conference on Firms and Trade, the World Bank Macroeconomics Seminar, and the UCLA Workshop in International Economics. The cooperation and participation of National Development Planning Agency (BAPPENAS) and Bada Pusat Statistik in Indonesia, Korea Institute for Industrial Economics and Trade (KIET), the Economic Planning Unit in the Prime Minister's Office in Malaysia, the National Statistics Office and the National Economic and Development Authority in the Philippines and the Thai Ministry of Industry are gratefully acknowledged. Financial support for collecting the data was received by the Policy and Human Resource Development Fund (Japan) and the Asia-Europe Meeting (ASEM) Trust Fund. The views expressed here are those of the authors and do not necessarily reflect those of The World Bank, its Executive Directors or member countries. The views expressed herein are those of the authors and not necessarily those of the National Bureau of Economic Research.
\end{abstract}

(C) 2002 by Mary Hallward-Driemeier, Giuseppe Iarossi and Kenneth L. Sokoloff. All rights reserved. Short sections of text, not to exceed two paragraphs, may be quoted without explicit permission provided that full credit, including (C) notice, is given to the source. 
Exports and Manufacturing Productivity in East Asia:

A Comparative Analysis with Firm-Level Data

Mary Hallward-Driemeier, Giuseppe Iarossi and Kenneth L. Sokoloff

NBER Working Paper No. 8894

April 2002

JEL No. O3, O1, O4, F1

\begin{abstract}
This paper uses new firm level data from five East Asian countries to explore the patterns of manufacturing productivity across the region. One of the striking patterns that emerges is how the extent of openness and the competitiveness of markets affects the relative productivity of firms across the region. Firms with foreign ownership and firms that export are significantly more productive, and the productivity gap is larger the less developed is the local market. We exploit the rich set of firm characteristics available in the database to explore the sources of export firms' greater productivity. We argue that it is in aiming for export markets that firms make decisions that raise productivity. It is not simply that more-productive firms self-select into exporting; rather, firms that explicitly target export markets consistently make different decisions regarding investment, training, technology and the selection of inputs, and thus raise their productivity.
\end{abstract}

Mary Hallward-Driemeier

The World Bank

1818 H Street NW

Washington, DC 20433

mhallward@worldbank.org
Giuseppe Iarossi

The World Bank

1818 H Street NW

Washington, DC 20433

giarossi@worldbank.org
Kenneth L. Sokoloff

Department of Economics

UCLA

Los Angeles, CA 90095 


\section{INTRODUCTION}

The spread of sustained and rapid economic growth throughout East Asia over the last forty years has attracted much attention from policymakers and economists. Although most agree that the remarkable record of progress has generally been based upon countries exploiting their comparative advantages in manufacturing, there remains much controversy over the patterns of these industrial expansions. One group of observers has contended that these economies not only realized extensive growth by mobilizing underutilized resources from other sectors to support dramatic expansion of export-oriented manufacturing, but that further gains came as competition in broad international markets with elastic demand induced improvements in productivity. ${ }^{1}$ Domestic firms that targeted global markets had substantial incentives to invest in improving the efficiency of their operations, and foreign firms had incentives to support technology transfer through a variety of means to economies with favorable factor endowments -- including direct investment. Proponents of this view also suggest that the rates of total factor productivity growth were unusually high because of the great potential for improving productivity that is typically present in early-industrializing economies, where many unproductive firms have long persisted, insulated from competition by local or otherwise segmented markets. They contend that a substantial one-time increase in productivity can be realized as rapid expansion of markets leads to better utilization of the resources in such firms as better (if not best) practices are adopted in order to survive or take advantage of the radical change in the environment. The breadth of international markets and opportunities for technology transfer offered East Asian economies during the late-20th century were rather

\footnotetext{
${ }^{1}$ See, for example, Pack and Westphal (2000) and Dollar and Sokoloff (1990).
} 
unprecedented, and this made possible an exceptional record of industrial development and progress.

An alternative perspective is that the rapid industrial growth stemmed virtually exclusively from rapid rates of factor accumulation - not of total factor productivity growth. In this view, the East Asian economies were remarkably effective at mobilizing and sustaining high rates of investment, but diminishing returns to, if not misallocation of, capital kept productivity growth at a quite modest pace. Those who share this perspective are typically skeptical of the notions that manufacturing productivity growth benefited particularly from the increased focus of East Asian firms on broad export markets, or from enhanced flows of foreign direct investment and technology transfer more generally. Alwyn Young $(1992,1995)$, for example, has argued that high rates of capital accumulation accounted for the bulk of the increase in manufacturing labor productivity over time in East Asian Tigers such as Hong Kong, Korea, Singapore, and Taiwan. ${ }^{2}$

Doubts about whether the expansion of exports led East Asian economies to realize more rapid productivity advance in manufacturing have been further reinforced by several recent studies that raise questions about the causal mechanisms underlying the well known empirical association across firms or industries between productivity and export orientation. Working with micro-level panel data from a number of different countries, scholars have found that firms tend to increase their productivity before beginning to export, rather than afterwards. Many have interpreted such findings as implying that it is productivity increase at the firm level that leads to greater export of output, rather than production for export leading to productivity advance. ${ }^{3}$

\footnotetext{
${ }^{2}$ Young (1992 and 1995).

${ }^{3}$ See, for example, Clerides, Lach, and Tybout (1998), Bernard and Jensen (1999).
} 
One of the reasons that this controversy endures is that the available data have not generally been rich enough to conclusively distinguish between the competing views. Specifically, most of the empirical work to date on East Asian manufacturing has had to rely on industry-level information over time. A great deal can and has been learned from investigations relying on such evidence, but the inability to directly examine whether and how productivity is related to firm characteristics leads to some uncertainty about the inferences that can be drawn. This problem may be particularly relevant to early developing economies where the initial stages of industrialization are often associated with substantial changes in manufacturing organization and technology, and poorly integrated markets allow firms with quite different levels of productivity to coexist during periods of transition. ${ }^{4}$ Another issue that has complicated efforts to study the sources of productivity with aggregate or industry-level time series data is that estimates of rates of growth are quite sensitive to the quality of the price indexes. Obtaining accurate and representative information on prices is always important for scholars of productivity, but the severity of the problem is ameliorated somewhat when the focus of analysis is on cross-sectional variation across firms within the same industry and economy. ${ }^{5}$

Concern with improving knowledge of manufacturing development has stimulated efforts to systematically collect and examine detailed information at the establishment level. Such data are often useful for studying the relationship between characteristics such as export orientation or access to broad markets and productivity. Among the crosssectional samples of manufacturing establishments that have become available are a new

\footnotetext{
${ }^{4}$ Many examples of this pattern can be drawn from the economic histories of now developed countries. For discussion of a relevant case during the early industrialization of the U.S., see Sokoloff (1984).

${ }^{5}$ This problem is admittedly more relevant to the older literature that focused on estimating productivity growth over time from industry- or sector-level data than it is to the more recent work that employs panel data on firms.
} 
set of surveys conducted across a wide range of countries with the encouragement and support of the World Bank. Although similar surveys have been carried out before, the recent emphasis on encompassing many countries and on comparability has made them more attractive and useful for researchers concerned with growth. This paper employs the first wave of these surveys, which were administered in five East Asian economies during the late 1990s: Indonesia, Korea, Malaysia, the Philippines, and Thailand.

Although the surveys enumerate establishments from only a limited number of industries within each economy, they are extremely rich in the information they contain. Not only is there extensive detail about the inputs consumed and outputs produced, but the data also include information on the governance of the firm, the ownership of the firm, the year in which the firm was established, the share of outputs exported, the use of outside auditors, the source of technology, and many other characteristics of the firms. There are typically two sorts of problems with cross-sectional studies of factors that might be related to productivity. One is that competition between firms typically limits the amount of variation in productivity that can be observed; hence estimates of systematic differentials in productivity tend to be downward biased in well-integrated markets. The second issue has to do with what is exogenous, what is endogenous, and what can be inferred about the sources and extent of productivity increase from an empirical association between productivity and firm characteristics.

In this paper, we show that, despite the questions that arise in working with such data, these cross-sectional surveys of firms can contribute much to our understanding of manufacturing productivity in East Asia. Although competition in well-integrated markets narrows the range of observed variation in firm performance, we find substantial 
advantages in productivity associated with firms that are in various senses more "open" to the rest of the world: those that foreigners have a greater ownership share in, those that use outside auditors, and those that choose to focus on the export market. Strikingly, we find that the magnitude of the differences in productivity related to these characteristics are extremely large in less-developed economies such as Indonesia and the Philippines, but are virtually absent in more-developed South Korea. This pattern is highly robust, and conforms well with the idea that there are major gains in productivity to be realized during the very early stages of industrial development.

We focus particular attention on the question of whether firms self-select to compete in world markets and make the appropriate investments that boost productivity and allow them to be successful in that broader arena, or whether relatively exogenous realizations of higher productivity allow the favored firms to export their output. To explore this issue, we take advantage of information collected by the surveys on whether or not the firm was an exporter during its first year of existence. In our view it is reasonable to take the behavior of the firm during its year of establishment as reflecting a relatively exogenous decision by the firm's creators about which market (export or exclusively domestic) to target. We show that firms that began as exporters not only have higher levels of productivity years later than other classes of firms, but that they also differ systematically in the training of their work forces, the vintage of their capital equipment, the use of auditing, and other aspects of their production processes and operations. We use this evidence to argue that it is in aiming for export markets that firms make a series of decisions that raise their productivity, and that such practices distinguish firms from their 
domestically oriented counterparts operating in less competitive or fully integrated local markets.

In sections II and III, we describe the manufacturing surveys we employ, and provide some descriptive statistics on what they reveal about the manufacturing sectors in the respective countries. We present our multivariate analyses in section IV. Section V concludes.

\section{DATA}

This paper uses new and comprehensive data from approximately 2700 manufacturing establishments in five East Asian countries: Indonesia, Korea, Malaysia, the Philippines, and Thailand. ${ }^{6}$ Instead of being restricted to a single country, this database provides comparable information on a wide set of firm characteristics for all of these five countries during the 1996-1998 period. With the assistance and advice of a World Bank team, similar instruments and sampling procedures (including industries selected for coverage) were employed to facilitate the cross-country comparisons. Enumerators personally gathered information from four to seven hundred firms in each country.

The survey questionnaires called for both qualitative and quantitative information. The qualitative section covered topics such as ownership structure, technology acquisition, views on the business environment, and relationships with banks and other financial institutions. The quantitative section included questions on production, financial accounts and human resources. In addition to collecting information on current operations, the survey asked for retrospective reports on the core quantitative variables over the previous

\footnotetext{
${ }^{6}$ We will use the terms firms, establishments, and plants interchangeably in the course of this paper, but it should be emphasized that the unit surveyed was the establishment - not the overall firm. For a more detailed description of the database, see Hallward-Driemeier (2000).
} 
year or two. The basic structure of the questionnaire employed was roughly the same across the countries.

The participating governments were particularly interested in issues related to the competitiveness of firms in manufacturing industries where there was potential for exports, and the survey was designed accordingly. In each country a large sample of establishments was selected from five to seven of the following industries or sectors: food processing, textiles, garments, chemicals, machinery, electronics, auto components, and wood products. The selected industries accounted together for more than half of the entire manufacturing value added, and of manufacturing exports, in each of the respective economies. Only registered firms with at least 20 employees were included in the population frame. ${ }^{7}$ This restricted population frame, assembled by each national statistical agency with technical assistance from the World Bank, was then used to randomly choose the sample of small, medium and large establishments to be interviewed.

Although considerable effort was directed at obtaining representative sets of establishments from the respective countries, there are some issues of sample selection to be considered. In drawing the sample, larger firms were over-sampled relative to their numbers in the overall population. A pure random sample would have resulted in very few observations of large firms, just as coverage of small firms would have been quite limited if the sample was based on the contribution to GDP. The proportions vary somewhat by country, but roughly a third of the sample is from each of the three size categories to allow

\footnotetext{
${ }^{7}$ There are two caveats. First, the Malaysian government was interested in building on a previous survey that had used the entire population of industrial firms, regardless of size. To make the sets of firms we worked with more comparable across countries, we excluded firms in Malaysia with less than 10 employees from our analysis. Despite this restriction, small firms account for a much higher proportion of the firms in the data we work with than they do for the other countries. See Table 1. The other point is that the size restriction employed in the design of the original samples was applied using information from the respective industrial registries. Some of the firms that had been listed in the registry as having 20 or more workers evidently experienced decreases in their labor force by the time they were surveyed.
} 
for a significant number of firms of each size to draw statistically significant inferences about each category. Within each size category, the establishments to be surveyed were selected randomly. ${ }^{8}$ One concern is whether our procedures for sampling by size categories captured the full extent of the differences in performance across sizes of firms. It is possible that by restricting our sampling frame to establishments with 20 or more employees, we constructed a sample that would be biased against finding differences in productivity across size. The surveys were completed in early 1999, but the samples of firms to be surveyed were drawn from various industrial registries that had generally been assembled one or two years before. Thus, newly established firms were underrepresented in our sample.

Another caveat is that we did not get full participation from all firms selected to be in our sample. Approximately $10 \%$ of sampled firms were either listed with an incorrect address or had failed between the time of the industrial registry and the interview. From the size, location and sectoral information we had from the registry lists, there appears to have been somewhat more attrition among the smaller firms, but no systematic differences across sectors or locations. In addition to this survivorship bias, there is some variation in response rates, particularly with regard to financial information. We were unable to receive outside verification of the accounting information supplied. And, despite our detailed instructions and examples, we cannot ensure that all firms used the same accounting definitions, particularly among smaller firms. While these caveats should be kept in mind, we have been careful in checking for the sensitivity of our qualitative

\footnotetext{
${ }^{8}$ The representation of large establishments is of course even greater if evaluated on the basis of their labor force allocation, with $90 \%$ of the workers employed by establishments in this largest size category. This result is driven in part of by a very few extremely large firms, i.e. with over 10,000 workers.
} 
findings and are not aware of any plausible sample selection biases that would lead to the robust results we report below. ${ }^{9}$

The one systematic test of representativeness we have been able to carry out was to compare the distribution of firms across industries (within each country) in the sample (see Table 1) to the distribution of firms across the same industries in the respective country's aggregate totals. Encouraging results were obtained; by the Mann-Whitney two-sample method, we could not reject the hypothesis that the sample was representative of the underlying population.

Table 1 presents descriptive statistics from the sample, with the upper panel relating the distributions of firms across particular categories and the lower panel providing the distributions of the labor force (firms weighted by the size of their labor forces) across the same categories. Several features of the data stand out. First, although the surveyed firms were drawn from some of the principal tradable goods sectors, many are not exporters. Overall, slightly more than half of all firms in the sample export some of their output, with the figures ranging from $75 \%$ in Korea to $39 \%$ in Indonesia. Because firms that export tend to be larger than those that do not, the shares of the labor force that work in firms that export some of their output (nearly $83 \%$ overall) are correspondingly higher. The proportion of firms that report some foreign ownership is not quite a quarter; of this quarter, foreigners own a majority share in $60 \%$. Again, however, since larger firms are more likely to have foreign owners (in all countries but Korea), the prominence of foreign ownership is greater if the gauge is based on where the labor force is employed. In general, there seems to be much less foreign direct investment in Indonesia and Korea, and

\footnotetext{
${ }^{9}$ In addition to the conventional problems of data retrieval and entry, we have also had to be concerned with whether firms followed good or standard accounting procedures, especially with smaller firms. See the data appendix for a detailed description of our treatment of outliers.
} 
more in the Philippines (as well as in Malaysia if we consider the size of firms surveyed).

These orderings are not the same as those implied by figures on the overall share of FDI in GDP, but part of the discrepancy may be due to FDI in resource extraction industries (which is especially important in Indonesia and Malaysia).

\section{LEVELS OF DEVELOPMENT AND THE IMPORTANCE OF CONTEXT}

The availability of comparable data for a number of developing East Asian economies provides an additional dimension along which to explore hypotheses about how and why conditions such as market size and intensity of competition generally, or export orientation in particular, are related to firm productivity. Simply put, theories that highlight mechanisms through which broader markets lead to higher levels of productivity among surviving firms imply that the gap in productivity between exporting and nonexporting firms should be larger in less developed economies where output markets are typically more segmented and limited in extent. A testable implication, therefore, is that the magnitude of the productivity differentials between firms that are more open (exporters) and less open (non-exporters) to broad international markets should diminish with the level of development. In contrast, the view that productivity improvements at the firm level are exogenous to the breadth of markets the firm faces does not yield a clear prediction about how the productivity differential varies across countries.

It should not be surprising that context may matter in making sense of the evidence, and in Table 2 we try to provide a sense of perspective through a conventional set of macroeconomic indicators and some statistics gleaned from the sample of manufacturing firms. Korea is obviously the most industrialized of the five countries. With a per capita 
income exceeding $\$ 11,000$, it qualified to join the OECD in 1996. Beginning in the 1960 s, the Korean government aggressively pursued industrial policies designed to promote manufacturing and exports. Often heralded as one of the 'miracle economies', its growth through the mid-1990s was indeed spectacular. As is suggested from it having the highest manufacturing share of GDP (36.8 percent), as well as the lowest agricultural share (5.8 percent), Korea has largely completed the transition from a substantially agricultural economy to a highly industrial urbanized one. With its high per capita income and elaborate infrastructure, Korea has the largest and most sophisticated domestic market of the five countries. This is also evident from its having the highest labor productivity and rate of investment in new machinery and equipment. The relatively low coefficient of variation in total factor productivity (TFP) is also consistent with the view that Korea has a more competitive and integrated market for manufacturing products.

The other four countries included in our data are all much less industrialized than Korea, but Malaysia would likely be judged as the most developed among them. Its GDP per capita is much higher than Thailand's (which in turn has a far higher GDP per capita than in the Philippines or Indonesia), even though the sectoral compositions of the two economies are quite similar. ${ }^{10}$ Although the latter's share of manufacturing in GDP is comparable, and its rates of investment overall and in new machinery are impressive, productivity remains much lower than in Korea or Malaysia, and Thailand has still not yet

\footnotetext{
${ }^{10}$ Another distinctive feature of the Malaysian economy is that, like in Korea, the government has been active in trying to direct the path of development. In recent years, the government has aggressively advocated specific sites as industrial areas, particularly focusing on attracting foreign firms in high technology industries. Another longstanding goal, however, has been to ensure that the indigenous population also benefited. In addition to various other affirmative action measures, the Bumiputras laws mandate that $30 \%$ of ownership must be in the hands of native Malays.
} 
managed to effect the transition from a focus on low value added manufacturing to one on higher value added activities.

The Philippines and Indonesia are clearly the least developed economies of the five, with per capita incomes and investment rates that are much lower than those of their neighbors. These two multi-island countries also have large and geographically dispersed populations, posing additional obstacles to the integration of markets. It is, accordingly, not at all surprising that agriculture accounts for a much larger share (and manufacturing smaller) of national output, nor that the coefficient of variation in manufacturing productivity is much higher, in these economies than in the other three countries.

While GDP per capita is a reasonable proxy for the extent of markets, we would also call attention to the relevance of the degree of dispersion in manufacturing productivity. When local or regional markets are not well integrated, a circumstance typical of less-developed countries, inefficient firms can survive because they are insulated from competition with more efficient enterprises - leading to greater productivity dispersion. Figure 1 depicts our gauge of the degree of dispersion, the coefficient of variation in manufacturing productivity, within each of the five countries. The dispersion patterns line up as would be expected from our knowledge of the development of the countries, with the highest variation in Indonesia, and lowest in Korea. There are some differences in relative dispersion across sectors, but in general the lower the level of development (as gauged by per capita income), the greater the relative number of less productive firms and the greater the dispersion in total factor productivity. ${ }^{11}$ This cross-

\footnotetext{
11 Haddad and Harrison (1993), Harrison (1994) and Levinsohn (1993) find consistent results that productivity dispersion decreased with greater competition post trade liberalization.
} 
country pattern is quite consistent with the view that the extent or integration of domestic markets can help understand the variation in manufacturing productivity.

\section{SYSTEMATIC PATTERNS IN TOTAL FACTOR PRODUCTIVITY}

The manufacturing surveys are a valuable resource for the study of manufacturing productivity in the newly-industrializing countries of East Asia. Not only do they provide researchers with detailed information at the firm level, but they also have the advantage of encompassing comparable industries (generally those with a marked potential for export) from a set of economies at much different levels of development. Thus, we can analyze variation in productivity and in other characteristics across firms within a country, as well as employ inter-country comparisons to check for robustness or to test implications of theories that bear on how patterns of productivity might vary across different market environments.

Our measures of total factor productivity (TFP) were derived from a Cobb-Douglas production framework (see Appendix for more details). We estimated a variety of different specifications of production functions in logarithmic form for each country separately. In one basic specification, output (calculated as total sales plus the change in inventories) was the dependent variable and the independent variables consisted of total assets, total employment, material inputs and energy, with dummy variables for sectors and years. $^{12}$ Output, inputs and total assets were converted to 1995 constant US dollars.

\footnotetext{
${ }^{12}$ The Malaysian questionnaire gathered information on the value of sales of the firm's most important product alone. However, for roughly half of the respondents the figures on total sales could also be retrieved. These four hundred observations were used to estimate the ratio of sales of the most important product to total sales, controlling for sector, size of firm, export status, ownership, and location. These fitted ratios were then used to estimate the values of total sales for the observations where that variable was not reported directly. In estimating the production functions, both the whole sample and the sub-sample for which we
} 
In the other basic specification, value added (calculated as output minus the value of raw materials and energy costs) was the dependent variable and the independent variables

were total assets and total employment.

We carried out extensive sensitivity analysis in estimating these production functions, experimenting with different measures of the inputs and outputs as well as with the precise subset of observations over which the functions were estimated. Concerned about possible simultaneity bias, we also followed procedures suggested by Olley and Pakes (1996) and Levinsohn and Petrin (2000) to generate semi-parametric estimates of productivity that would be consistent even in the presence of input shares being influenced by private knowledge of a firm's productivity. ${ }^{13}$ The basic patterns in the data are so strong that the qualitative results are extremely robust to the use of different procedures or specifications. ${ }^{14}$ The production function parameters we employed for the analyses of systematic variation in total factor productivity presented below were estimated over a sub-sample of establishments that employed 10 or more workers and had provided the required information; extreme outliers were excluded. ${ }^{15}$

knew the total sales were used. The former demonstrated larger scale effects. This would be consistent with smaller firms producing a larger number of products on a made to order basis.

${ }^{13}$ Our use of these procedures was of course confined to the production functions estimated with total output as the dependent variable. Although these procedures have come to be commonly used to adjust for the possible simultaneity bias that conventional methods of production function estimation suffer from, they too are based on strong and somewhat implausible assumptions. For discussion, see Ackerberg (2002).

${ }^{14}$ One concern is that given the timing of the survey, we might get significant variation across years. However, while there are shifts in the average productivity in 1998, the hypothesis that the input coefficients are equal over time cannot be rejected. Thus, we opted to include year dummies in the regressions. We also ran the regressions for each year separately and the qualitative results held.

${ }^{15}$ About 20 firms in each country were excluded on the basis of one or more of the relevant variables, such as the capital to labor ratio or measures of productivity, were more than 4 standard deviations from the mean. 
In Table 3, we report the sets of output elasticities obtained from four different specifications of production functions, with each normalized to sum to one. ${ }^{16}$ As is clear, they vary across countries, but are generally within ranges suggested by the work of other investigators. ${ }^{17}$ These country-specific output elasticities were then used to compute sets of establishment-level estimates of TFP, corresponding to the different specifications of production functions. The basic qualitative results of the multivariate analyses presented below are again highly robust to the selection of production function specification the respective measure of TFP is based on. ${ }^{18}$

In order to explore the systematic patterns in manufacturing productivity, we estimated a variety of multivariate regressions across the firms within each country, with different measures of the log of total factor productivity as the dependent variable, and a set of dummy variables controlling for sector, year, firm size, whether the firm was located in the capital city, the extent of foreign investment in the firm, whether output was exported during the year the firm was established, whether the firm was not established as an exporter but became an exporter later, and a variety of other characteristics included as independent variables. We report, in Tables $4 a, 4 b$, and 4c, the results from the regressions based on TFP measures derived from the two different

\footnotetext{
${ }^{16}$ The estimates suggest that there were scale economies in four of the five countries, with their magnitude being greatest in the least-developed economies such as Indonesia and the Philippines. In the lower panel, we report the point estimates of the scale coefficient for each country, as derived from the series estimator. ${ }^{17}$ These output elasticities were estimated from production functions that included dummy variables for industries. We did not allow for output elasticities that varied across industries, because inclusion of such interaction variables did not significantly increase the explanatory power of the production functions. Moreover, the qualitative results we report below were robust to how we treated this issue.

${ }^{18}$ While the basic qualitative results are robust, the size of the coefficients does vary. In particular, as is typical in production function estimation, the use of specifications with output rather than value added as the dependent variable reduce the estimates of the extent of scale economies as well as differences in productivity between classes of firms substantially. Intuitively, this results from there being relatively limited variation in the output to materials ratio over firms, because the scope for producing a unit of output without certain raw materials is limited. The differences can be seen across Tables $4 \mathrm{~b}$ through $4 \mathrm{~d}$, when one compares the regressions using estimates of TFP based on gross output with those based on value added as the measure of output.
} 
production function specifications: the series estimator (based on the Levinsohn-Petrin procedure for dealing with simultaneity) and the more conventional OLS Cobb-Douglas specification with value added as the measure of output. What is immediately striking about the results of these regressions is how similar they are across the five countries, as well as how sensible the empirical regularities are.

First, the evidence is broadly consistent with the notion that there are substantial economies of scale during the earliest stages of industrial development. As foreshadowed by the scale coefficients we reported in the lower panel of Table 3, even when we control for many other characteristics, the estimated coefficients on the dummy variables for establishment size suggest that smaller firms are far less productive than their larger counterparts in the less-developed economies such as Indonesia and Thailand, but are essentially just as productive in more-developed Korea. ${ }^{19}$ This contrast is perhaps not surprising, in that the more extensive and competitive product markets associated with higher levels of development would be expected to be more effective at selecting out firms with markedly lower productivity, and accordingly reduce the range of observed productivity differentials across size and other firm characteristics. Presuming the reasonableness of drawing inferences from comparisons of cross-sectional results over economies at different stages of development, the implication seems to be that there may be a substantial one-time gain in manufacturing productivity during the early stages of development, associated with the shift of resources out of traditional small-scale

\footnotetext{
${ }^{19}$ This qualitative result held across virtually all specifications we estimated. It does not hold for the Philippines when we use the measure of TFP obtained from the series estimator, and also control for other establishment characteristics (such as whether the firm has foreign owners and exports), but it is robust to the series estimator if one doesn't control for these other variables that are highly correlated with size (see the lower panel of Table 3). As noted above, the surprisingly extensive scale economies estimated for Malaysia may be related to problems in the way output was reported in that country. See footnote 12.
} 
establishments to larger enterprises operating with more modern organizations and technologies.

Another factor that has been suggested as an important source of manufacturing productivity growth in developing countries is the involvement of foreigners. The basic logic is that when foreign individuals and companies, who are thought to be more familiar with technological opportunities, have direct interests in the performance of a firm, they will have a greater ability or incentive to invest in diffusing or implementing improvements in technology or management. These stimuli to technology transfer lead firms that have closer associations with foreigners to raise their productivity above the level at which they would otherwise operate. Our data make it possible to examine this hypothesis directly, and we find that even after controlling for sector, size, and export orientation, firms in which foreigners have a substantial ownership share have markedly higher productivity than those that are domestically owned in four of the five countries surveyed. ${ }^{20}$ Moreover, comparing the coefficients on the two variables reflecting different extents of foreign ownership implies that firms with foreign ownership shares of over 50 percent stand out especially in productivity. That this discontinuity in the estimated relationship between foreign ownership and productivity conforms so well with the intuition that foreigners would be more inclined, and capable, of investing in transfer of technology where they have a controlling share in the firm bolsters confidence in the interpretation that the result is not an artifact, and that the principal line of causation went from foreign ownership to productivity. Moreover, that the estimated productivity

\footnotetext{
${ }^{20}$ Malaysia deviates from this pattern somewhat in that the result that firms with foreign ownership are more productive is not robust. In some specifications, and especially if all firms with any foreign ownership are grouped together, the point estimate of the association with productivity is positive. It may be the case that the relationship is different in Malaysia because of the special programs there to obtain a significant ownership share for native Malays.
} 
differentials are largest in the least developed countries of Indonesia and the Philippines, where the estimates are around 40 percent by the series-estimator measure of TFP (as compared to 15 to 20 percent in Korea and Thailand), is generally consistent with this idea. $^{21}$

One of the most controversial potential sources of productivity growth in developing countries is the orientation toward the export market. There is a longstanding view in economics that firms are more productive in more extensive markets. Several mechanisms have been proposed, including economies of scale, notions that more extensive markets put more competitive pressure on firms to keep up with the technological edge, and the idea that larger markets, with presumably more elastic demand, offer greater returns to investment in invention or in other means of increasing value per unit cost. Based on this tradition, as well as abundant evidence from developing countries of general associations between the importance of exports and productivity across industries or firms, many have argued that firms that focus on the export market do realize increases in their productivity. Indeed, additional reasons for why orientation towards exports might promote higher productivity have been suggested, such as it making it easier to learn about advanced technologies employed elsewhere. ${ }^{22}$ Proponents of this school contend further that developing economies should specialize in those goods in which they enjoy a comparative advantage, to boost rates of productivity and economic growth.

\footnotetext{
${ }^{21}$ The data contain information about the nationality of the foreign owners, but we find no significant relation between any particular nationality and firm productivity.

22 Prominent among them are that firms might raise productivity over time through learning by doing, or through advice or technical assistance provided by foreign customers - directly or through intermediaries. Kraay (1999) and Bigsten et. al. (2000) provide evidence of the importance of learning by exporting in China and several African economies. Also see Pack and Westphal (1998) and Westphal (2001).
} 
Although intuitively appealing, it has been difficult to substantiate the view that if firms focus more on exports they will come to realize higher productivity. Skeptics have noted how a reverse path of causation might be able to account for an empirical association between exports and productivity. For example, a recent study by Clerides, Lach, and Tybout (CLT) (1998), uses firm-level panel data from Colombia, Mexico, and Morocco to make the case that productivity may be higher among exporters because firms are better able to export after they increase productivity. In other words, the empirical pattern follows from higher productivity to exports, not from involvement in the world or export to higher productivity. ${ }^{23}$ In these panels, CLT found a roughly constant differential in productivity over time between firms that exported throughout the period covered by the data and those who never exported during those years. Hence these groups had roughly the same rate of productivity growth. The only firms that appeared to register higher average rates of productivity growth over the sample periods were those that moved from being non-exporters to exporters; moreover, most of the relative productivity increase (or decrease in costs of production) preceded the shift to exporting. Similarly, the firms that transitioned from exporting to not exporting manifested a decrease in productivity before changing status.

Clerides, Lach and Tybout were especially concerned with exploring whether exporting affects the productivity of firms through learning-by-doing. They reasoned that if so, firms should "exhibit a change in the stochastic process that governs their productivity growth" after beginning to export, and thus their analysis focused on a comparative examination of the productivity trajectories of different classes of firms.

\footnotetext{
${ }^{23}$ Similar conclusions of the importance of the selection of higher productivity firms into export markets are found in Bernard and Jensen (1999) and Aw, Chung and Roberts (2000).
} 
Although their treatment was meticulous and richly informative, the more general question of whether there is an impact of a firm exogenously choosing to focus on exports may not be fully resolved by their findings. There are two issues we have in mind. First, there may be constraints on the ability to observe persistent differences in productivity trajectories when the samples are confined to surviving firms. More specifically, the productivity trajectory of the low-productivity firms that survive in competition with the high-productivity firms may be determined by the rate at which the latter increase their productivity. Low-productivity firms that lag further and further behind will eventually fail --and that process of attrition puts bounds on the magnitude of the productivity differentials revealed by the data. The second issue is how to date the effect of a firm deciding to export. If a firm must make preparations or investments beforehand in order to compete in the world market, the effects of exporting on productivity may begin early, and indeed might be evident before any goods are actually exported. ${ }^{24}$

The East Asia enterprise surveys contain on the years when firms were established and on when they began to export, and thus allow us to apply an alternative method of trying to sort out the different paths of causation behind the association between exporting and productivity. Our approach is based on taking the orientation of the firm at the time of its establishment (whether or not they exported within a year of beginning operations) as exogenous, and comparing domestic firms that began as exporters with both domestic firms that began as non-exporters but made the transition to exporting, and domestic firms that never exported. The logic is that firms that export during their first

\footnotetext{
${ }^{24}$ In other words, we are asking whether it is more reasonable to think of firms deciding to focus on the export market and then making investments that would allow them to compete in that market, or to think of the improvements that CLT observe prior to exporting as being realized exogenously with respect to involvement in the export market. See Westphal (2001) for a discussion of how exporting firms often are established with commitments from foreign buyers already in hand.
} 
year in existence must have intended to compete in the broader international market before commencing operations, and thus the choice of their orientation was exogenous with respect to productivity. ${ }^{25}$ Figure 2 presents the distributions, for each country, of the length of time that passed between the year the firm was established and the year it first exported. Up to two-thirds of the firms that were exporters in our sample began exporting within two years of beginning operations. Thus, for a significant number of firms the decision to export was likely made before any realization of productivity. One of the reasons why this figure is so high is that only a very tiny fraction of firms that were established as exporters had stopped exporting by the time the manufacturing surveys were conducted. ${ }^{26}$ In support of our view that firms that were established as exporters are quite different from those that were not, in Figure 3 we present for three classes of firms the distributions of firms by the shares of output that are exported in the year of the survey: domestic firms that were originally established as exporters (that is, export in the year of establishment); domestic firms that were originally non-exporters but exported at some point before the survey; and firms that had foreign owners. As is evident, domestic firms established as exporters resemble foreign-owned firms in having higher export shares or being much more specialized at the export market than those that transitioned to exporting later in their histories. Such evidence tends to bolster our claim that a substantial, if not dominant, proportion of firms that export were likely intended right from their initial organization to focus on the export market. We contend that this class of firms is an especially interesting one to focus on, both because they can provide insight

\footnotetext{
${ }^{25}$ Although the logic seems compelling, it must be admitted that the success at carrying through on that orientation - actually exporting during the first year of operations - may not be strictly exogenous with respect to productivity.

${ }^{26}$ The pattern is even stronger in that virtually all of the firms that ever exported part of their output were exporting at the time of the surveys.
} 
into the effects of an exogenous decision to compete in a broad international market, and because the class accounts for a quantitatively important share of domestic firms that export. $^{27}$

Given the logic of our approach to getting at the impact of involvement in export markets, and because most of the theories about the export-productivity linkage relate to domestically-owned firms, we interact export orientation during the first year and whether the firm is domestically owned in the total factor productivity regressions. Table 4a presents the results of the regressions where this interaction term is included (and where the measure of TFP is derived from the production functions with the series estimator). It is striking in that four of the five countries (all but relatively-advanced Korea), the coefficients imply that the domestically-owned firms that had been exporters during the year of their establishment were much more productive than their counterparts that had not begun as exporters, with the differentials largest in the least-developed economies: the Philippines and Indonesia, followed by Thailand and Malaysia. Moreover, the qualitative results are quite robust and hold across alternative measures of TFP or whether or not we distinguish between the firms that made the transition to exporter status after establishment from the persistent non-exporters (see Table $4 b$ and $4 c$ ). In this latter case, the point estimates of the productivity advantage for the original exporters consistently exceed those for the firms that made the transition from non-exporters to exporters in

\footnotetext{
${ }^{27}$ There are, of course, several potential problems with our interpretation. First, we are not actually observing all of the firms that were organized with the intent of focusing on the export market, but rather firms that were so organized and were successful. Second, there is an unobserved heterogeneity problem in that owners of firms organized to aim for the export market may be more talented than those that are content to target the domestic market. In principle, these issues may help account for our results. Our efforts to address these concerns are discussed below.
} 
each of the four countries, although they are not quite always significantly different from each other. $^{28}$

It should be noted that the results we obtain are not inconsistent with the results of CLT. The data are organized a bit differently, but in both studies the early exporters are markedly more productive than the non-exporters, and those firms that began exporting later have an average productivity that falls between the two extreme groups. Our interpretation of this pattern is different, however, in that we suggest that firms choosing to export tend to change the manner of operating so as to be able to compete effectively in the more competitive wider market. In our view, producing for the export market can lead to higher productivity through mechanisms other than learning (or the form of learning as specified in CLT), such as through inducing firms that seek the potentially higher rewards available to exporters to make new investments to upgrade their efficiency even as they are just beginning their operations.

The substantial differences in total factor productivity between domestic firms that were established as exporters and domestic firms that were not (and especially those that do not export) we observe in the less-developed East Asian economies are certainly consistent with our view that entrepreneurs that decide to focus on the export market make a conscious decision to operate differently from those that rely on the domestic market, and thus realize greater value per unit of input. Before accepting this interpretation, however, there are several fundamental issues that must be resolved. First,

\footnotetext{
${ }^{28}$ Korea is the exceptional case. As has been suggested before, one would expect to observe smaller differentials in productivity across classes of firms in a relatively more developed economy such as Korea. Thus, the small and insignificant difference between original exporters and other domestically-owned firms is not surprising. The pattern across countries also helps to assuage doubts about the effect of the crisis driving our results. In Korea, a country that did experience the crisis in 1998, exporters were not more productive than non-exporting firms. In the Philippines, however, a country that largely escaped the crisis, the same pattern holds as in Thailand and Indonesia.
} 
there is the question of how the evident co-existence of firms in the same industry with such radically different levels of productivity can be explained. If these firms were competing directly against each other, the less productive firms would not have been able to survive and we should not be able to observe such a dramatic gap. If the less productive firms were insulated from competition, and thus able to survive despite much lower productivity, what factors could have accounted for that protection? Conditions such as poor infrastructure and high transportation costs, which are generally recognized as obstacles to integrated product markets in less-developed economies, surely play some role, especially in making sense of the extensive scale economies observed in the leastdeveloped societies. However, the most important barrier or source of market segmentation may be in the quality of specifications of the product items. The textile goods produced for export in Indonesia, for example, are likely to be very different from those produced for the domestic market. If the more productive of the available technologies is linked to producing the higher quality of product demanded in the international market (but not to the same degree in the home market), a situation that seems quite reasonable if the newer technologies are developed abroad, then it is quite possible to observe a difference in average productivity between firms focusing on the export market and those focusing on the domestic market.

Few would dispute the idea that the quality or specifications of products could be a powerful factor in accounting for segmented product markets in less-developed economies. Skeptics might ask, however, whether it is reasonable to compare the productivity of classes of firms producing very different products, even if they are nominally classified as being within the same industry. We argue that it is entirely 
reasonable in this context, particularly because the differences in the character or nature of the inputs being utilized in the respective production processes are either small or captured in market prices (such as the evaluation of the capital stock). In our view, given that different products are assessed and aggregated with market prices, comparisons of the amount of total value produced per unit of input are very useful indicators of relative productivity in manufacturing - just as they are in agriculture. This perspective rests to some degree on the inputs, at least those not evaluated at market prices, being rather similar in nature. The composition of the labor force is the obvious subject of concern here, but, as shown in Table 5, domestic firms established as exporters have a labor force much like that of those that were not established as exporters (in the four countries where this information was collected). Although firms with a significant foreign-ownership share have a markedly more educated workforce than either, the two classes of domestic firms have a close resemblance in this regard. Such evidence that the inputs being used are comparable supports the logic of drawing inferences about relative productivity from information about how much value the respective classes of domestic firms generate per unit of input. $^{29}$

Even accepting that the inputs being used by the firms that export are quite similar, or appropriately evaluated by market prices, another problem about the comparability of the productivity estimates could be raised. It might be argued that the technologies employed by the two classes of firms are so different that in computing total factor

\footnotetext{
${ }^{29}$ We were able to run TFP regressions with controls for the proportions of the labor force that had different levels and types of education (i.e. primary, secondary, vocation, or tertiary) in the four of the five countries that reported such information (all but Indonesia). The coefficients on the variables controlling for the education of the workers had the expected signs and were statistically significant, but the effects were small in magnitude. The qualitative results concerning the relative productivity of foreign-owned, domestic exporters, and domestic firms focused on the domestic market were not at all sensitive to such controls.
} 
productivity, the use of the output elasticity estimates for capital and labor obtained from a single production function is a source of bias and could affect the qualitative results. Specifically, given that the export-oriented firms were more capital intensive than those directed at the domestic market, our procedures could make the former seem relatively more productive than they actually were if they led to an underestimation of their output elasticity of capital relative to that of labor. This possibility might seem plausible if the different technology that exporters employed was capital-augmenting in some way, and if our measures of the value of the capital stock were inadequate. We explored the significance of this potential problem in two ways. First, we estimated production functions over domestically-owned firms with interaction terms between the inputs they employed and a dummy variable for whether they were exporters; the estimated coefficients on these terms were very small and insignificantly different from zero in statistical terms. We also reran the same regressions with TFP measures based on the value added conception of output we reported above, but with much higher elasticities or weights ( 0.8 and even 0.9$)$ on the capital input than is feasible. Employing such unrealistically high weights on capital definitely biases the productivity estimates against the more capital-intensive export-oriented firms, yet the basic qualitative results we reported hold. The clear implication is that the amounts of output produced by the domestically-owned firms relative to inputs are so high, as compared to the same ratio among those firms geared toward the domestic market, that the qualitative findings are extremely robust to reasonable variation in the ways the estimations and comparisons are carried out. 
Thus far, both evidence and theory seems quite consistent with our view that after choosing to focus on exports, entrepreneurs made investments in to raise the productivity of their plants and the quality of the goods they produced so as to be able to compete effectively in the potentially more lucrative international market. Another obvious test of our hypothesis, however, is to examine whether firms that export conduct themselves very differently from those that do not. If our perspective is to offer any explanatory power, we should see evidence that exporting firms were distinctly different in their mode of operations, other than in simply getting more value of output per unit of input. One of the most basic elements of how a firm operates is the types and amounts of inputs it employs, and we accordingly examined how different classes of enterprises, as defined by their export status and whether they are domestic, varied along this dimension. As is evident from the regressions presented in Table $6 \mathrm{a}$ and $6 \mathrm{~b}$, domestic firms that export are substantially different in their capital intensity and vintage of capital equipment from their counterparts that do not, and indeed more closely resemble the enterprises that are foreign owned. After controlling for the age of the firm, size, sector, year, and establishmentlevel reports of their rate of capacity utilization, we find in Table 6a that in all five countries domestic firms that exported as well as foreign-owned firms are both markedly more capital intensive (as judged by the ratio of assets to the number of workers) than domestic firms that do not export. Moreover, as demonstrated in equation Table $6 \mathrm{~b}$ the same classes of firms are generally (though not in Indonesia) also distinguished by having larger shares of their capital stock composed of equipment of recent vintage (0-4 years old), even after controlling for the age of the firm. Foreign-owned firms typically went even further than domestically-owned exporters in pursuing both of these types of 
investments, which would normally be thought of as conducive to increasing productivity. What is more relevant here, however, is that even after controlling for size and other firm characteristics, domestic firms that export make significantly different choices about their production techniques than those that do not. They more closely resemble the foreign-owned firms in both these decisions, as well as in realizing significantly higher levels of productivity.

In Table 7, we examine in more detail the differences in practice across classes of firms by presenting descriptive statistics for two industries, textiles and electronics, surveyed in each of the five countries. Reported are the median number of workers, the median capital per worker, the share of firms who used outside auditors to review accounts, the share of firms with formal training programs, the share of firms that indicate they were using technology obtained from abroad. The figures lend further support to the notion that even within the same industry domestic firms that export operate very differently from those that do not, with the exporters looking more like firms with foreign owners in how they are run. The finding that both classes of domestic exporters (those that were established as exporters and those that began exporting later) and foreignowned firms are typically substantially larger than the domestic firms that focus on the local market is perhaps not surprising, but it is interesting to note that the differences are generally greatest in the less developed economies like Indonesia, the Philippines, and Thailand, and smallest in Korea. Even more striking are the contrasts in the use of independent auditors and formal employee training programs, where again firms with foreign owners and domestically-owned enterprises that export are much more progressive than those who produce only for the domestic market. In Thailand's textile 
industry, for example, the proportion of domestically-owned exporters that use outside auditors is roughly the same (indeed slightly higher) as that for firms with foreign owners (50 and 61 percent to 48 percent), and all are much higher than for enterprises that confine themselves to the domestic market (27 percent). The pattern is similar for employee training programs, with 50 and 26 percent of the two classes of domesticallyowned exporters having them, as compared to 46 percent of firms with foreign owners and only 17 percent for those selling domestically. Although the numbers bounce around somewhat, largely due we think to small cell sizes, the only country of our group of five that deviates from this pattern is the more developed Korea (especially with electronics). Overall, the evidence suggests that domestic enterprises that choose to produce for the export market make systematically different choices about how to operate, and that their choices lead them to function more like foreign-owned firms, realize higher productivity, and more effectively compete in an international market.

Some might question whether the features we have highlighted in our comparison could really be all that significant in accounting for the higher productivity of domesticowned exporters. It could, for example, be argued that the greater prevalence of practices such as formal employee training and the use of outside auditors among this class of enterprises might merely reflect the larger size or ownership structure of these firms. The regressions reported in Tables $8 \mathrm{a}-\mathrm{b}$ and $9 \mathrm{a}-\mathrm{b}$, however, tend to undercut that possibility. Returning to the specification where the log of total factor productivity is the dependent variable (and using measures of TFP based on the series estimator and the value added approach respectively in $8 \mathrm{a}$ and $8 \mathrm{~b}$ ), we add dummy variables for the use of outside auditors and of employee training programs, as well as for different ownership structures 
(sole proprietorship, partnership, or corporation) to the same list of independent variables used above. Although the results are not fully robust to all countries and specifications, the results indicate that even after controlling for size and a wide range of other characteristics, enterprises that use outside auditors and employee training programs generally have higher productivity than their peers that did not. The significant association of these practices with productivity is all the more remarkable in that there is no consistent relationship (see regressions in Table 9a and 9b) between productivity and the variables reflecting the ownership structure (such as whether the firm is a partnership, publicly listed corporation, or whether its shareholders have limited liability). Given the recent emphasis by many economists on corporate governance issues, the contrast between the relative insignificance of these variables in explaining differentials in productivity across firms relative to other factors is impressive. ${ }^{30}$

We have, up to now, given only limited attention to the conditions or individual characteristics behind the decisions by entrepreneurs to aim at the export market, and to carry out investments to boost productivity and prepare for competition in that arena. Our treatment, however, has implied that more entrepreneurs would tend to move in this direction as fundamental factors associated with the process of growth as well as national policies improve the effective degree of access of domestic producers to foreign markets. Our analysis suggests that such changes in the orientation toward exports lead to increases in the productivity of resources employed in manufacturing, but this effect would depend to some degree upon the supply of entrepreneurial talent. For example, it might be argued that individuals with the talent and other characteristics necessary for

\footnotetext{
${ }^{30}$ It is unclear why Thailand seems to depart from this pattern, largely due to its single proprietorships being markedly less productive than other types of firms.
} 
great success as entrepreneurs are particularly scarce in the less-developed East Asian economies, and that the relatively high productivity of domestically-owned exporters we find in such countries was due entirely to the concentration of scarce entrepreneurial talent in those firms. If this were true, our interpretation of the cross-sectional patterns might change, and implications for the growth over time of manufacturing productivity of a country encouraging exports would depend on how elastic, in both the short- and longrun, the supplies of entrepreneurial talent were.

We are unable to measure the quality of entrepreneurs directly, but we have sought to investigate the significance of the relative scarcity of such talent in the less-developed countries by using information from the surveys on whether the founder of the firm had previous experience in the industry, and whether the experience was with a local or domestically-owned firm, a foreign-owned firm, or a joint venture. In Table 10, we report TFP regressions (based on the series estimator), with dummy variables for the backgrounds of the founders of the firms employed, in addition to the basic variables included above, as the independent variables. The results indicate that firms with founders that had previous experience in the industry, and especially experience at joint ventures, were significantly more productive than their counterparts in all countries except for Korea. ${ }^{31}$ This pattern is quite consistent with the notion that the scarcity of entrepreneurial talent is greater in less-developed economies. Despite this evidence that the experience of the founder is related to the productivity in the least-developed economies, it is perhaps even more striking that the qualitative finding of productivity being higher among firms established as exporters is robust to such controls for the

\footnotetext{
${ }^{31}$ This association between the experience of the founder and the productivity of his firm is suggestive of there being positive externalities stemming from foreign investment.
} 
characteristics of the entrepreneur. As before, the productivity gap between the domestic firms that began as exporters and those that did not is: large, positive, and statistically significant in Indonesia, the Philippines, and Thailand; positive but only marginally significant in Malaysia; and essentially zero in most-developed Korea. Although there are many other relevant characteristics of entrepreneurs that we are unable to discern, the lack of sensitivity of the cross-sectional patterns to this control for heterogeneity in the quality of entrepreneurs provides further support for our interpretation.

Overall, the evidence suggests that increasing the orientation of enterprises toward exports, and promoting greater openness more generally, is likely to stimulate more rapid productivity growth in manufacturing, especially in the least developed economies, whose domestic markets might be expected to be less competitive or more segmented on the basis of quality of goods. First, firms that are foreign-owned, and particularly those controlled by foreign owners, have higher productivity than domestic firms - even after controlling for other characteristics. Given that, at least among these countries, foreigners should have greater access to knowledge about technology and management techniques as well as to capital, the qualitative finding may not be surprising. One implication of the rather large productivity differentials, however, is that the less developed among the industrializing countries do indeed make more productive use of their resources when they receive foreign investment, and that openness toward such flows is good policy.

Another important finding of this cross-sectional analysis is that orientation toward exports is associated with higher productivity. Although more study is needed, our attention to the experience of enterprises that begin to export from the very first year of 
their establishment suggests that the lure of broader markets does induce firms to operate more like foreign-owned firms and, as a result, realize higher productivity and compete more effectively in the international arena. We believe that our new approach to getting around the problem of causation in considering the relationship between productivity and export, does contribute to a better understanding of the phenomenon.

\section{Conclusion}

In this paper we have employed firm-level surveys to study manufacturing productivity in five East Asian economies. In contrast to the aggregated time series used by many previous investigators, our data offer rich detail about the operations of firms. Moreover, although only a limited number of industries were surveyed, each is quite diverse with respect to firm characteristics such as size, the extent of foreign ownership, the orientation toward the export market, and the structure of ownership and governance.

Our results suggest strongly that in early-industrializing Asian economies total factor productivity has generally been much higher among firms that are integrated into broader markets. This pattern is reflected in the estimation of economies of scale, as well as in the higher productivity among firms that export, firms that foreigners have a significant ownership stake in, and among firms that employ outside auditors. These findings are all the more striking in that no other variables, including those that many have speculated about -- such as whether the firm is organized as a sole proprietor, partnership, or corporation - had a consistent relationship with productivity.

Another feature of the evidence that lends further support to our interpretation is that the magnitude of the estimated differentials in productivity are largest in the least 
developed economies of Indonesia and the Philippines, still substantial in Thailand, and smallest in the most developed economies of Malaysia and especially South Korea. That is, it is in the least developed economies, where less-integrated markets protect less efficient firms from competition and allow them to survive, that we observe major gains in productivity among firms that are clearly integrated into broader markets. In the more industrialized countries such as South Korea, however, where domestic markets are likely already quite integrated, firms focused on the domestic market are roughly equivalent to their peers producing for the broad international market. One implication drawn about changes over time from these cross-sectional patterns, is that the early industrializers of East Asia, such South Korea, may have realized a substantial (if one-time) advance in productivity as their markets expanded and became more integrated during their initial stages of industrial development. To those concerned with the design of policy (whether in countries such as Indonesia or in the U.S.), the message would be that it is the least developed economies that have the most to gain from measures that would broaden the markets they face.

Skeptics have often objected to drawing inferences about the beneficial effects of broader markets on productivity from observations of an empirical association between productivity and a proxy for involvement in broader markets such as the export of output. They have correctly pointed out that the causation underlying such an association can work in either direction. Recognizing the importance of this point, we tackled this problem by exploiting information contained in the surveys on the year the firm was established and the year the firm first exported part of its product. Although very few, if any, phenomena are ever purely exogenous, we have argued that it is reasonable to treat firms that exported 
from their time of establishment as having focused on preparing to compete in the broad international market before their productivity was realized. Finding that this class of firms was more productive than those that came to export later or never exported is consistent with causation operating from an entrepreneur's decision to effectively compete in broader markets to higher productivity. Our data do not allow us to probe very deeply into the circumstances that led some entrepreneurs to aim for the export market while others did not. Nevertheless, the robustness of our findings to controlling for the backgrounds of the firm founders, as well as intuition, provide support for the notion that the expansion of opportunities to export in less-developed economies (such as through reductions in the trade barriers they face) would lead more entrepreneurs to focus on the export market, and thus to increases in overall manufacturing productivity. The results of this analysis may not be conclusive, but they do highlight the significance of one of the processes involved in the growth of manufacturing productivity in newly-industrializing East Asian economies that is difficult to isolate in aggregated data. A clear implication is that more work with micro-level evidence needs to be done if we want our understanding of manufacturing productivity growth in developing economies to be at all comprehensive. 


\section{Appendix: Estimation Procedures}

Productivity is assumed to be an unobserved plant-specific effect that can be recovered from an estimated production function as the difference between actual and predicted output. Such an approach raises econometric issues regarding the possible bias of coefficients on input variables due to simultaneity bias. The concern is that the productivity of the firm itself affects the input decisions, introducing correlation between the plant effect and the input coefficients. If there is simultaneity bias, simply running OLS will lead to biased estimates of the input coefficients ${ }^{32}$. Three means of addressing this problem are examined here.

The most common approach is to assume that the unobserved firm heterogeneity is time-invariant so that a fixed effects estimators is appropriate. However, such an approach dispenses with all variation between firms. With a short panel, and with an expectation that the cross-sectional variation will be more important (and better measured) than the time series dimension, we do not have much confidence in this approach. Indeed a number of authors have pointed out the shortcomings of such an estimator.

A second approach is to use instrumental variables, selecting variables that would be correlated with the factor's share, but not with the productivity shock. Additional assumptions regarding the nature of the productivity shock have to be made. Firms would have to have some advance private knowledge of their productivity shock and adjust their fixed factors accordingly. Thus, recognizing the needed lead time to invest, firms may increase their capital stock in anticipation of a positive productivity shock. The instrument we use is the lagged share of energy costs. This will be correlated with the capital stock, but not with any change in expected productivity. Such a technique is also justified to address the possible concern of measurement error in the capital stock. However, if productivity shocks are correlated over time, the instrument is no longer valid.

An alternative approach is one advanced by Olley-Pakes (1996) and modified by Levinsohn-Petrin (2000). Productivity can be thought of as having two components $\omega_{\text {it }}+$ $\eta_{\text {it. }} \eta_{\text {it }}$ is truly random each period, but $\omega_{\text {it }}$ could be known to the firm, although unobserved to the econometrician. In such a situation, firms could adjust their inputs based on their knowledge of the anticipated or known productivity component, introducing the simultaneity bias. Olley-Pakes assume that labor and materials are freely variable inputs, but capital is treated as a state variable, affected by the distribution of the productivity shock, $\omega_{i t}$, conditional on the information at t-1 and past values of $\omega_{i}$. Their insight is that other observable firm decisions will be a function of the productivity of the firm, and that inverting such a function allows for the anticipated but unobserved productivity shock to be controlled for using the observed variables. They argue that investment is a function of the anticipated productivity shock and provided a monotonicity assumption holds, they can invert the function, with productivity as a function of investment.

\footnotetext{
${ }^{32}$ While the bias on labor and on capital could go either way, most commonly, there would be an upward bias on the labor coefficient and a downward bias on the capital coefficient. That selection cannot be controlled for could exacerbate the biases.
} 
One drawback of the approach is simply practical. The technique requires non-zero investments by firms, a criteria that would imply half our observations be dropped. Noting this likely difficulty, Levinsohn-Petrin instead argue that intermediate input demand functions can play the same role. They use the demand for electricity to illustrate their point. It is an input used by all firms. And as it cannot be stored, it closely tracks the productivity term over time. We follow their example here ${ }^{33}$.

Thus, the regression ( $l=$ labor, $m=$ materials, $e=$ energy, $k=$ capital $)$ is:

$$
y_{i t}=a+\beta_{l} l_{i t}+\beta_{m} m_{i t}+\beta_{e} e_{i t}+\beta_{k} k_{i t}+\omega_{i t}+\eta_{i t}
$$

The productivity shock $\omega_{i t}$ is unobserved, but is assumed to be correlated with $\mathrm{e}_{i t}$ and $\mathrm{k}_{\mathrm{it}}$ so that estimates of $\beta_{\mathrm{e}}$ and $\beta_{\mathrm{k}}$ are biased. However, as the demand for electricity is a function of $\omega_{i t}$ and $k_{i t}, e\left(\omega_{i t}, k_{i t}\right)$, and assuming it is invertible, $\omega_{i t}$ can be rewritten as a function of $\mathrm{e}_{\mathrm{it}}$ and $\mathrm{k}_{\mathrm{it}}$. 34

$$
\omega_{\text {it }}=\mathrm{h}\left(\mathrm{e}_{\mathrm{it}}, \mathrm{k}_{\mathrm{it}}\right)
$$

Substituting (2) in (1), one can estimate the following equation in the first stage of the procedure:

$$
y_{i t}=a+\beta_{l} l_{i t}+\beta_{m} m_{i t}+\beta_{e} e_{i t}+\beta_{k} k_{i t}+h\left(e_{i t}, k_{i t}\right)+\eta_{i t}
$$

Not knowing the functional form of $\mathrm{h}\left(\mathrm{e}_{\mathrm{it}}, \mathrm{k}_{\mathrm{it}}\right)$-- in particular not knowing if it also has a linear terms in $\mathrm{e}_{\mathrm{it}}$ and $\mathrm{k}_{\mathrm{it}}$-- one cannot sort out the coefficients $\beta_{\mathrm{e}}$ or $\beta_{\mathrm{k}}$. We included a fourth-order polynomial expansion in $\mathrm{e}_{\text {it }}$ and $\mathrm{k}_{\mathrm{it}}$ (including all the interaction terms) to approximate the form of $\mathrm{h}($.$) . The inclusion of the polynomial removes the difficulty in$ estimating the coefficients on variable inputs; $\beta_{1}$ and $\beta_{\mathrm{m}}$ will be consistent. From this stage we also have an estimate of the fourth order polynomial in $\mathrm{e}_{\mathrm{it}}$ and $\mathrm{k}_{\mathrm{it}}$, call it $\varphi_{\mathrm{it}}$.

$$
\varphi_{i t}=\beta_{e} e_{i t}+\beta_{k} k_{i t}+h\left(e_{i t}, k_{i t}\right)
$$

Rearranging, $h\left(e_{i t}, k_{i t}\right)=\varphi_{i t}-\beta_{e} e_{i t}+\beta_{k} k_{i t}$

Looking at the expectation of $y_{i, t+1}-\beta_{1} 1_{i, t+1}-\beta_{m} m_{i, t+1}$ and assuming $\omega_{i t}$ is serially correlated, one can then rewrite $\omega_{i t+1}$ as a function of $\omega_{i t}\left(i . e . ~ o f ~ h\left(e_{i t}, k_{i t}\right)\right)$. As $h\left(e_{i t}, k_{i t}\right)$ is a function of $\mathrm{e}_{\mathrm{it}}$ and $\mathrm{k}_{\mathrm{it}}$ instead of $\mathrm{e}_{\mathrm{it}+1}$ and $\mathrm{k}_{\mathrm{it}+1}$, one no longer has $\beta_{\mathrm{e}} \mathrm{e}_{\mathrm{it}}$ and $\beta_{\mathrm{k}} \mathrm{k}_{\mathrm{it}}$ in both the main and the $h($.$) parts of the equation. Not knowing the functional form, we again used a$

\footnotetext{
33 While we follow the logic of Levinsohn and Petrin's paper and use electricity demand rather than the investment equation, our estimation procedures are closer to those suggested by Olley-Pakes. Levinsohn and Petrin favor local least squares and a GMM estimator in the last stage, while we found the series estimator to be easier to implement. However, Olley-Pakes suggest both a kernel and series estimator, favoring the former as its limiting distribution is known. They note that the two estimates are very similar. Following Pavcnik's (2000) example, we also use the series estimator and boot-strap the standard errors.

${ }^{34} \mathrm{~A}$ second assumption is that markets are competitive so that all firms face the same prices.
} 
fourth order polynomial expansion in $\mathrm{h}($.$) and substitute in h\left(e_{i t}, k_{i t}\right)=\varphi_{i t}-\beta_{e} e_{i t}+\beta_{k} k_{i t}$. Using non-linear least squares, the coefficients $\beta_{\mathrm{e}}$ and $\beta_{\mathrm{k}}$ can then be estimated.

$$
y_{i t+1}-\beta_{l} l_{i t+1}+\beta_{m} m_{i t+1}=c+\beta_{e} e_{i t+1}+\beta_{k} k_{i t+1}+h(\cdot)+h^{2}(\cdot)+h^{3}(\cdot)+h^{4}(\cdot)+\eta_{i t}
$$

Thus, following on these two papers, we use a semi-parametric estimator that provides a plant-specific, time-varying productivity measure. It does not require a specific functional form, requiring few restrictive assumptions. The coefficients are unbiased, providing a tractable solution to the simultaneity problem.

An additional source of potential bias regards the selection of firms that remain in the sample. While the data covers three years, all firms were in operation in the last year so we do not have information on firms that would have been in operation but exited during the time covered by the study. While the available data will not allow us to estimate and control for selection bias, we note that it is an issue, and that the capital coefficient could likely be biased downward and the labor coefficient biased upwards.

The production function is run separately for each country. We did not want to make assumptions that technology used across countries was the same or to restrict input coefficients to be the same across countries. For each country, we have 5 to 7 sectors. We did pool the sectors within a country and run a single production function for each country. We then tested the restriction that the input coefficients were the same across sectors. ${ }^{35}$ While the null hypothesis that such a restriction was valid was not rejected in Indonesia, Thailand and Korea, it was rejected for Malaysia and the Philippines. While we reported the pooled results, we also reran the equations separately for each sector within each country. One drawback of such a procedure is that the sample size for some sectors is quite small, decreasing the confidence in some of the estimates. For the second stage of the paper, where the productivity measures are then regressed on a number of firm characteristics, the overall qualitative results still hold whether or not one uses the constrained or unconstrained regressions.

Input variables are expressed in logarithms so the coefficients can be interpreted as elasticities.

\footnotetext{
${ }^{35}$ Such tests were made using the OLS regressions.
} 


\section{Bibliography}

Ackerberg, Daniel. (2002) "Notes on the Structural Estimation of Production Functions," unpublished working paper.

Aitken, Brian, Gordon Hanson and Ann Harrison. (1997) "Spillovers, Foreign Investment and Export Behavior." Journal of International Economics, 43(1/2): 103-132.

Aitken, Brian and Ann Harrison (1999). "Do Domestic Firms Benefit from Foreign Direct Investment? Evidence from Venezuela." American Economic Review. 89 (3): 605618.

Aw, Bee Yan, Sukkyun Chung and Mark Roberts. (2000). "Productivity and the Turnover in the Export Market: Micro-level Evidence from the Republic of Korea and Taiwan (China)," The World Bank Economic Review, 14 (1): 65-90.

Aw, Bee Yan and A.R. Hwang. (1995) "Productivity and the Export Market: A Firm-Level Analysis," Journal of Development Economics, 47, pp. 313-332.

Bayoumi, Tamim, David Coe and Elhanan Helpman. (1999) "R\&D Spillovers and Global Growth," Journal of International Economics, 47 (2): 399-428.

Bernard, Andrew and Bradford Jensen. (1999) Exceptional Exporter Performance: Cause, Effect, or Both?" Journal of International Economics. 47 (1): 1-25.

. (1997) "Why Firms Export: Experience, Entry Costs, Spillovers and Subsidies," unpublished working paper (Yale University).

Bigsten, Arne, Paul Collier, Stefan Dercon, Marcel Fafchamps, Bernard Gauthier, Jan Willem Gunning, Jean Habarurema, Abena Oduro, Remco Oostendorp, Catherine Pattilo, Mans Soderbom, Francis Teal and Albert Zeufack. (2000) "Exports and Firm-Level Efficiency in African Manufacturing", Centre of the Studies of African Economies, Working Paper Series 2000-16.

Blomstrom, Magnus and Ari Kokko. (1996) "The Impact of Foreign Investment on Host Countries: A Review of the Empirical Evidence", The World Bank Policy Research Working Paper Series, No. 1745.

Clerides, Sofronis, Saul Lach and James Tybout. (1998) "Is 'Learning-by-Exporting" Important? Micro-Dynamic Evidence from Colombia, Mexico and Morocco", Quarterly Journal of Economics, 113 (4): 903-947.

Dollar, David and Kenneth Sokoloff. (1990) "Patterns of Productivity Growth in South Korean Manufacturing Industries, 1963-1979", Journal of Development Economics, 33 (4): 309-327.

Dollar, David and Mary Hallward-Driemeier. (2000) "Crisis, Adjustment and Reform in Thailand's Industrial Firms," World Bank Research Observer, 15 (1):1-22. 
Dwor-Frecaut, Dominique, Francis Colaco, and Mary Hallward-Driemeier (eds.). (2000) Asian Corporate Recovery: Findings from Firm-Level Surveys in Five Countries, Washington DC: The World Bank.

Haddad, Mona. (1993) "The Link Between Trade Liberalization and Multi-Factor Productivity: The Case of Morocco." World Bank Discussion Paper Series, No. 4.

Haddad, Mona and Ann Harrison. (1993) "Are There Spillovers from Direct Foreign Investment? Evidence from Panel Data for Morocco." Journal of Development Economics.

Hallward-Driemeier, Mary (2000). "Asian Corporate Crisis and Recovery Firm-Level Survey: A Database of 4000 Firms in Indonesia, Korea, Malaysia, the Philippines and Thailand," World Bank Policy Research Working Paper, No. 2515.

Harrison, Ann. (1994). "Productivity, Imperfect Competition and Trade Reform", Journal of International Economics, 36 (1): 53-73.

Hsieh, Chang-Tai. (1999) "Productivity Growth and Factor Prices in East Asia," American Economic Review. Vol. 89 (2): 133-138.

Kraay, Aart. (1999) "Exports and Economic Performance: Evidence from a Panel of Chinese Enterprises," Revue d'Economie Du Developpement, (2): 183-207.

Levinsohn, James. (1993) "Testing the Imports-As-Market-Discipline Hypothesis," Journal of International Economics, Vol. 35, (1/2): 1-22.

. (1996) "Firm Heterogeneity, Jobs and International Trade: Evidence from Chile," National Bureau of Economic Research Working Paper, No. 5808 (Cambridge MA).

Levinsoh, James and Amil Petrin. (2000) "Estimating Production Functions Using Inputs to Control for Unobservables," National Bureau of Economic Research Working Paper, No. 7819 (Cambridge MA).

Liu, Lili and James Tybout. (1996) "Productivity Growth in Chile and Columbia: The Role of Entry, Exit and Learning," in M. Roberts and J. Tybout (eds.) Industrial Evolution in Developing Countries. Oxford: Oxford University Press.

Olley, Steven and Ariel Pakes. (1996) "The Dynamics of Productivity in the Telecommunications Equipment Industry," Econometrica, 64 (6): 1263-1297.

Pack, Howard and Larry Westphal. (1998). "Industrial Strategy and Technological Change: Theory versus Reality," in Industrial Policy and Competitive Advantage, David Audretsch (ed.).

Pavcnik, Nina. (2000) "Trade Liberalization, Exit and Productivity Improvements: Evidence from Chilean Plants," unpublished working paper (Dartmouth College). 
Reinikka, Ritva and Jakob Svensson. (1999) "Confronting Competition: Investment Response and Constraints in Uganda," unpublished working paper (World Bank).

Roberts, Mark and James Tybout. (1996) Industrial Evolution in Developing Countries: Micro Patterns of Turnover, Productivity and Market Structure. New York: Oxford University Press.

Rodrik, Dani. (1997) "TFPG Controversies, Institutions and Economic Performance in East Asia." National Bureau of Economics Research Working Paper, No. 5914 (Cambridge, MA).

Sokoloff, Kenneth L. (1984) "Was the Transition from the Artisanal Shop to the NonMechanized Factory Associated With Gains in Efficiency: Evidence from the U.S. Manufacturing Censuses of 1820 and 1850," Explorations in Economic History, 21 (4): 351-382.

Tybout, James. (2000) "Manufacturing Firms in Developing Countries: How Well do they do and Why?," Journal of Economic Literature, 38 (1):11-45.

Tybout, James and Daniel Westbrook. (1995) "Trade Liberalization and the Dimensions of Efficiency Change in Mexican Manufacturing Industries", Journal of International Economics, 39 (1): 53-78.

Wacziarg, Romain. (1998) "Measuring the Dynamic Gains from Trade," unpublished working paper (World Bank).

Westphal, Larry E. (2001) "Technology Strategies for Economic Development in a Fast Changing Global Economy," unpublished working paper (Swarthmore College).

Young, Alwyn. (1995) "The Tyranny of Numbers: Confronting the Statistical Realities of the East Asian Growth Experience." Quarterly Journal of Economics, 110 (2): 641680 .

. (1992) "A Tale of Two Cities: Factor Accumulation and Technical Change in Hong Kong and Singapore." NBER Macroeconomics Annual. 


\section{Table 1. Descriptive Statistics}

Share of firms with Different Characteristics

\begin{tabular}{|c|c|c|c|c|c|c|}
\hline & Indonesia & Korea & Malaysia & Philippines & Thailand & 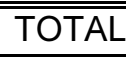 \\
\hline \multicolumn{7}{|l|}{ Export Orientation } \\
\hline Non-Exporter & 61.7 & 25.0 & 52.5 & 47.1 & 43.4 & 46.1 \\
\hline Exporter & 38.3 & 75.0 & 47.5 & 52.9 & 56.6 & 53.9 \\
\hline of which: Domestic & 67.3 & 80.9 & 52.1 & 43.7 & 55.7 & 62.6 \\
\hline FDI & 32.7 & 19.1 & 47.9 & 56.3 & 44.3 & 37.4 \\
\hline \multicolumn{7}{|l|}{ Foreign Owned } \\
\hline No ( $<10 \%$ of equity) & 84.2 & 83.1 & 73.5 & 64.7 & 69.5 & 76.0 \\
\hline Yes ( $\geq 10 \%$ of equity) & 15.8 & 16.9 & 26.5 & 35.3 & 30.5 & 24.1 \\
\hline of which: Minority $(<50 \%)$ & 6.9 & 51.1 & 29.8 & 33.5 & 70.7 & 38.8 \\
\hline Majority $(\geq 50 \%)$ & 93.1 & 48.9 & 70.2 & 66.5 & 29.3 & 61.2 \\
\hline \multicolumn{7}{|l|}{ Size } \\
\hline Small (<50 workers) & 26.6 & 23.1 & 47.4 & 23.0 & 31.5 & 30.6 \\
\hline Medium (50-149 workers) & 26.7 & 42.2 & 25.3 & 24.0 & 30.8 & 30.2 \\
\hline Large ( $\geq 150$ workers) & 46.7 & 34.8 & 27.3 & 53.0 & 37.7 & 39.1 \\
\hline \multicolumn{7}{|l|}{ Industries } \\
\hline Food & 31.7 & & 22.1 & 23.9 & 10.1 & 18.0 \\
\hline Textiles & 12.7 & 23.2 & 7.0 & 15.1 & 22.2 & 15.7 \\
\hline Garments & 13.9 & & 19.4 & 23.2 & 31.8 & 16.6 \\
\hline Const. Materials & & & 14.4 & & & 3.1 \\
\hline Chemicals & 29.2 & 28.4 & 16.7 & 17.3 & & 19.5 \\
\hline Machinery & & 17.6 & 7.1 & & & 5.3 \\
\hline Electronics & 12.6 & 16.9 & 9.8 & 20.5 & 16.4 & 14.9 \\
\hline Autoparts & & 13.9 & 3.5 & & 19.5 & 6.9 \\
\hline
\end{tabular}

\section{Distribution of Labor Force}

\begin{tabular}{|c|c|c|c|c|c|c|}
\hline & Indonesia & Korea & Malaysia & Philippines & Thailand & TOTAL \\
\hline \multicolumn{7}{|l|}{ Export Orientation } \\
\hline Non-Exporter & 27.6 & 7.5 & 15.9 & 14.6 & 15.5 & 17.3 \\
\hline Exporter & 72.4 & 92.5 & 84.1 & 85.4 & 84.5 & 82.7 \\
\hline of which: Domestic & 64.8 & 54.7 & 33.1 & 31.8 & 41.5 & 48.4 \\
\hline FDI & 35.2 & 45.3 & 66.9 & 68.2 & 58.5 & 51.6 \\
\hline \multicolumn{7}{|l|}{ Foreign Owned } \\
\hline No (<10\% of equity) & 69.4 & 56.8 & 40.0 & 40.3 & 46.2 & 54.0 \\
\hline Yes ( $\geq 10 \%$ of equity) & 30.7 & 43.3 & 60.0 & 59.7 & 53.9 & 46.1 \\
\hline of which: Minority $(<50 \%)$ & 5.4 & 87.8 & 20.1 & 29.0 & 66.9 & 42.6 \\
\hline Majority ( $\geq 50 \%)$ & 94.6 & 12.2 & 79.9 & 71.0 & 33.1 & 57.5 \\
\hline \multicolumn{7}{|l|}{ Size } \\
\hline Small (<50 workers) & 1.8 & 2.0 & 3.6 & 1.4 & 2.7 & 2.1 \\
\hline Medium (50-149 workers) & 5.2 & 10.4 & 12.2 & 5.1 & 9.1 & 7.9 \\
\hline Large ( $\geq 150$ workers) & 93.1 & 87.5 & 84.3 & 93.6 & 88.1 & 90.0 \\
\hline \multicolumn{7}{|l|}{ Industries } \\
\hline Food & 25.4 & & 8.6 & 21.1 & 21.7 & 16.0 \\
\hline Textiles & 18.6 & 20.1 & 14.5 & 7.7 & 15.2 & 16.0 \\
\hline Garments & 22.5 & & 7.2 & 21.7 & 25.6 & 15.6 \\
\hline Const. Materials & & & 12.7 & & & 1.6 \\
\hline Chemicals & 19.3 & 23.1 & 14.7 & 10.3 & & 15.2 \\
\hline Machinery & & 11.6 & 7.8 & & & 3.7 \\
\hline Electronics & 14.2 & 34.0 & 28.5 & 39.3 & 22.5 & 26.4 \\
\hline Autoparts & & 11.2 & 6.1 & & 15.1 & 5.6 \\
\hline Total number of firms & 587 & 694 & 607 & 424 & 406 & 2,718 \\
\hline
\end{tabular}

Source: World Bank, Asian Corporate Crisis \& Recovery Firm-Level Survey 1999. 
Table 2. Indicators of Level of Development

\begin{tabular}{|c|c|c|c|c|c|}
\hline & Indonesia & Korea & Malaysia & Philippines & Thailand \\
\hline \multicolumn{6}{|l|}{ Macro } \\
\hline GDP per capita & $\$ 1,105$ & $\$ 11,467$ & $\$ 4,625$ & $\$ 1,122$ & $\$ 3,017$ \\
\hline Gross Domestic Investment, \% GDP & 31.8 & 34.2 & 42.8 & 24.8 & 33.3 \\
\hline Manufacturing Value Added, \% GDP & 25.6 & 28.9 & 27.8 & 22.8 & 28.2 \\
\hline Agricultural Value Added, \% GDP & 16.7 & 5.8 & 11.7 & 20.6 & 11.1 \\
\hline Urban Population, \% of total & 37.7 & 79.7 & 55.2 & 20.6 & 55.8 \\
\hline \multicolumn{6}{|l|}{$\begin{array}{l}\text { Share of New Machinery } \\
\text { \& Equip-t (less 4yr old) }\end{array}$} \\
\hline in $10-19 \mathrm{yr}$ old firms & 18.1 & 36.4 & 23.8 & 24.4 & 21.7 \\
\hline in $20-29 \mathrm{yr}$ old firms & 15.1 & 29.3 & 22.1 & 19.9 & 22.4 \\
\hline $\begin{array}{l}\text { Median Value Added/worker } \\
\text { (\$'000 ppp) }\end{array}$ & 3.1 & 39.2 & 10.0 & 5.0 & 6.7 \\
\hline Coefficient of variation of TFP & 5.03 & 0.20 & 0.70 & 1.84 & 0.92 \\
\hline
\end{tabular}

Source: World Bank, 2001 World Development Indicators, Washington DC (data refer to 1997) and World Bank, Asian Corporate Crisis \& Recovery Firm-Level Survey 1999 


\section{Table 3}

\section{Normalized Output Elasticities Obtained from Different Production Function Specifications}

\begin{tabular}{|c|c|c|c|c|c|}
\hline & Indonesia & Korea & Malaysia & Philippines & Thailand \\
\hline \multicolumn{6}{|c|}{ OLS with Value Added Measure of Output } \\
\hline Labor & 0.49 & 0.38 & 0.74 & 0.56 & 0.61 \\
\hline Capital & 0.51 & 0.62 & 0.26 & 0.44 & 0.39 \\
\hline \multicolumn{6}{|c|}{ OLS with Gross Output Measure of Output } \\
\hline Materials & 0.49 & 0.21 & 0.40 & 0.51 & 0.64 \\
\hline Labor & 0.21 & 0.28 & 0.30 & 0.23 & 0.19 \\
\hline Capital & 0.20 & 0.43 & 0.16 & 0.13 & 0.09 \\
\hline Energy & 0.10 & 0.08 & 0.14 & 0.13 & 0.09 \\
\hline \multicolumn{6}{|l|}{ Fixed Effects } \\
\hline Materials & 0.44 & 0.31 & 0.31 & 0.43 & 0.67 \\
\hline Labor & 0.21 & 0.21 & 0.30 & 0.25 & 0.07 \\
\hline Capital & 0.19 & 0.40 & 0.15 & 0.09 & 0.03 \\
\hline Energy & 0.16 & 0.09 & 0.24 & 0.23 & 0.23 \\
\hline \multicolumn{6}{|l|}{ Series Estimator } \\
\hline Materials & 0.46 & 0.22 & 0.33 & 0.46 & 0.58 \\
\hline Labor & 0.19 & 0.23 & 0.32 & 0.20 & 0.18 \\
\hline Capital & 0.28 & 0.49 & 0.32 & 0.18 & 0.23 \\
\hline Energy & 0.07 & 0.06 & 0.03 & 0.16 & 0.02 \\
\hline
\end{tabular}

Scale Effects

\begin{tabular}{lccccc}
\hline & Indonesia & Korea & Malaysia & Philippines & Thailand \\
\cline { 2 - 6 } Series Estimator & 1.18 & 1.01 & $1.09^{*}$ & 1.16 & 1.12 \\
\hline \hline
\end{tabular}

\footnotetext{
* Calculated using subsample of firms which report total sales and just not sales of most important product. See Appendix for discussion on production function estimation.

Source: World Bank, Asian Corporate Crisis \& Recovery Firm-Level Survey 1999
} 


\section{Table 4a}

Pooled Cross-Section Variation in Total Factor Productivity Across Firms, by Countries: Regressions using TFP Measures from Series Estimator Production Functions

\begin{tabular}{|c|c|c|c|c|c|}
\hline & (1) & (2) & (3) & (4) & (5) \\
\hline & Indonesia & Korea & Malaysia & Philippines & Thailand \\
\hline \multirow[t]{2}{*}{ Domestic, Established as Exporter ${ }^{1}$} & 0.206 & -0.005 & 0.149 & 0.228 & 0.133 \\
\hline & $(3.26)^{\star *}$ & $(0.15)$ & $(1.62)$ & $(3.23)^{\star *}$ & $(2.38)^{\star}$ \\
\hline \multirow{2}{*}{ Minority Foreign Ownership ${ }^{2}$} & & 0.078 & -0.030 & 0.074 & 0.012 \\
\hline & & $(1.89)$ & $(0.30)$ & $(1.56)$ & $(0.35)$ \\
\hline \multirow[t]{2}{*}{ Majority Foreign Ownership ${ }^{3}$} & 0.375 & 0.158 & -0.012 & 0.352 & 0.221 \\
\hline & $(6.16)^{\star \star}$ & $(4.42)^{* *}$ & $(0.13)$ & $(6.99)^{\star *}$ & $(3.67)^{* *}$ \\
\hline \multirow[t]{2}{*}{ Medium (50-149) } & 0.082 & 0.004 & 0.342 & 0.046 & 0.092 \\
\hline & $(1.83)$ & $(0.16)$ & $(5.57)^{\star *}$ & $(1.07)$ & $(2.64)^{\star *}$ \\
\hline \multirow[t]{2}{*}{ Large (150 plus) } & 0.332 & 0.014 & 0.233 & 0.062 & 0.083 \\
\hline & $(7.47)^{\star *}$ & $(0.47)$ & $(2.46)^{*}$ & $(1.49)$ & $(2.29)^{*}$ \\
\hline \multirow[t]{2}{*}{ Capital city } & 0.041 & 0.072 & 0.155 & 0.102 & 0.047 \\
\hline & $(0.96)$ & $(2.98)^{\star \star}$ & $(2.28)^{*}$ & $(2.94)^{\star *}$ & (1.31) \\
\hline \multirow[t]{2}{*}{ Age Dummy ${ }^{4}$} & -0.043 & 0.006 & 0.240 & 0.019 & -0.065 \\
\hline & $(1.15)$ & $(0.17)$ & $(3.86)^{\star \star}$ & $(0.51)$ & $(1.95)$ \\
\hline Observations & 842 & 1644 & 967 & 780 & 748 \\
\hline R-squared & 0.26 & 0.39 & 0.35 & 0.54 & 0.30 \\
\hline
\end{tabular}

The dependent variable is the productivity measure constructed using the sector by sector series estimator. Sector dummies and year dummies were included, but not reported.

Robust t-statistics in parentheses; * significant at $5 \%$; ** significant at $1 \%$

Note: ${ }^{1}$ Dummy variable: $1=$ firm with less than $10 \%$ of equity foreign owned and that started exporting within the first year of establishment; currently is exporter. $0=0$ therwise.

${ }^{2}$ Dummy variable: $1=$ firm with $10 \%$ to $49 \%$ of equity foreign owned; $0=$ otherwise.

${ }^{3}$ Dummy variable: $1=$ firm with $50 \%$ or more of equity foreign owned.

${ }^{4}$ Dummy variable: $1=$ firm established 10 or more years ago; $0=0$ otherwise

Source: World Bank, Asian Corporate Crisis \& Recovery Firm-Level Survey 1999 
Table 4b

Pooled Cross-Section Variation in Total Factor Productivity Across Firms, by Countries: Regressions using TFP Measures from Series Estimator Production Functions

\begin{tabular}{|c|c|c|c|c|c|}
\hline & (1) & $(2)$ & (3) & $(4)$ & (5) \\
\hline & Indonesia & Korea & Malaysia & Philippines & Thailand \\
\hline \multirow[t]{2}{*}{ Domestic, Established as Exporter ${ }^{1}$} & 0.236 & 0.012 & 0.218 & 0.285 & 0.121 \\
\hline & $(3.71)^{\star *}$ & $(0.30)$ & $(2.31)^{*}$ & $(3.90)^{* *}$ & $(1.96)$ \\
\hline \multirow[t]{2}{*}{ Domestic, Became Exporter ${ }^{2}$} & 0.082 & 0.024 & 0.151 & 0.146 & -0.023 \\
\hline & $(1.69)$ & $(0.79)$ & $(1.96)$ & $(2.94)^{\star *}$ & $(0.61)$ \\
\hline \multirow[t]{2}{*}{ Minority Foreign Ownership ${ }^{3}$} & & 0.096 & 0.040 & 0.134 & 0.002 \\
\hline & & $(2.01)^{*}$ & $(0.39)$ & $(2.57)^{*}$ & $(0.05)$ \\
\hline \multirow[t]{2}{*}{ Majority Foreign Ownership ${ }^{4}$} & 0.408 & 0.175 & 0.060 & 0.409 & 0.212 \\
\hline & $(6.45)^{\star \star}$ & $(4.10)^{\star *}$ & $(0.62)$ & $(7.64)^{* *}$ & $(3.35)^{\star *}$ \\
\hline \multirow[t]{2}{*}{ Medium (50-149) } & 0.061 & 0.002 & 0.308 & 0.020 & 0.096 \\
\hline & (1.38) & $(0.08)$ & $(4.83)^{\star \star}$ & $(0.45)$ & $(2.64)^{* *}$ \\
\hline \multirow[t]{2}{*}{ Large (150 plus) } & 0.299 & 0.009 & 0.195 & 0.028 & 0.090 \\
\hline & $(6.25)^{\star \star}$ & $(0.31)$ & $(2.02)^{*}$ & $(0.65)$ & $(2.25)^{*}$ \\
\hline \multirow[t]{2}{*}{ Capital city } & 0.044 & 0.073 & 0.152 & 0.096 & 0.049 \\
\hline & $(1.03)$ & $(2.99)^{\star \star}$ & $(2.20)^{*}$ & $(2.74)^{\star \star}$ & $(1.34)$ \\
\hline \multirow[t]{2}{*}{ Age Dummy 5} & -0.047 & 0.002 & 0.238 & 0.023 & -0.064 \\
\hline & $(1.26)$ & $(0.06)$ & $(3.83)^{* *}$ & $(0.59)$ & $(1.92)$ \\
\hline Observations & 842 & 1644 & 967 & 780 & 748 \\
\hline R-squared & 0.26 & 0.39 & 0.35 & 0.55 & 0.30 \\
\hline
\end{tabular}

Sector dummies and year dummies were included, but not reported.

Robust t-statistics in parentheses; * significant at 5\%; ** significant at $1 \%$

Note: ${ }^{1}$ Dummy variable: $1=$ firm with less than $10 \%$ of equity foreign owned and that started exporting within the first year of establishment; currently is exporter. $0=0$ otherwise.

${ }^{2}$ Dummy variable: $1=$ firm with less than $10 \%$ of equity foreign owned and that started exporting sometime after the first year of establishment; currently is exporter. $0=0$ otherwise.

${ }^{3}$ Dummy variable: $1=$ firm with $10 \%$ to $49 \%$ of equity foreign owned; $0=0$ otherwise.

${ }^{4}$ Dummy variable: $1=$ firm with $50 \%$ or more of equity foreign owned; $0=$ otherwise.

${ }^{5}$ Dummy variable: $1=$ firm established 10 or more years ago; $0=0$ otherwise

Source: World Bank, Asian Corporate Crisis \& Recovery Firm-Level Survey 1999 


\section{Table 4c}

Variation in Total Factor Productivity across Firms: Pooled Cross-Section Regressions with TFP Measures Based on OLS Value Added Production Functions

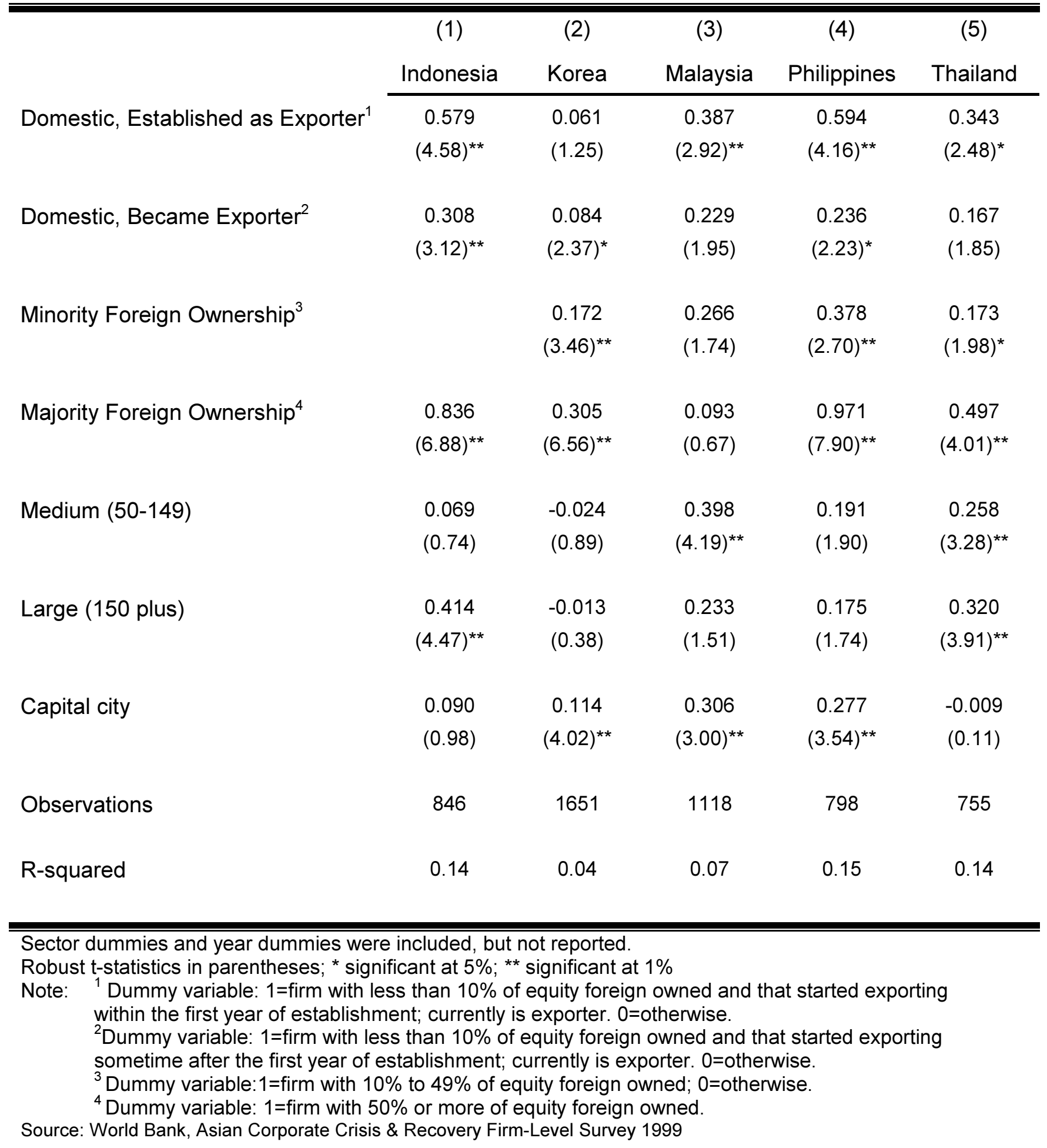


Table 5

Composition of the Work Force By Level of Education

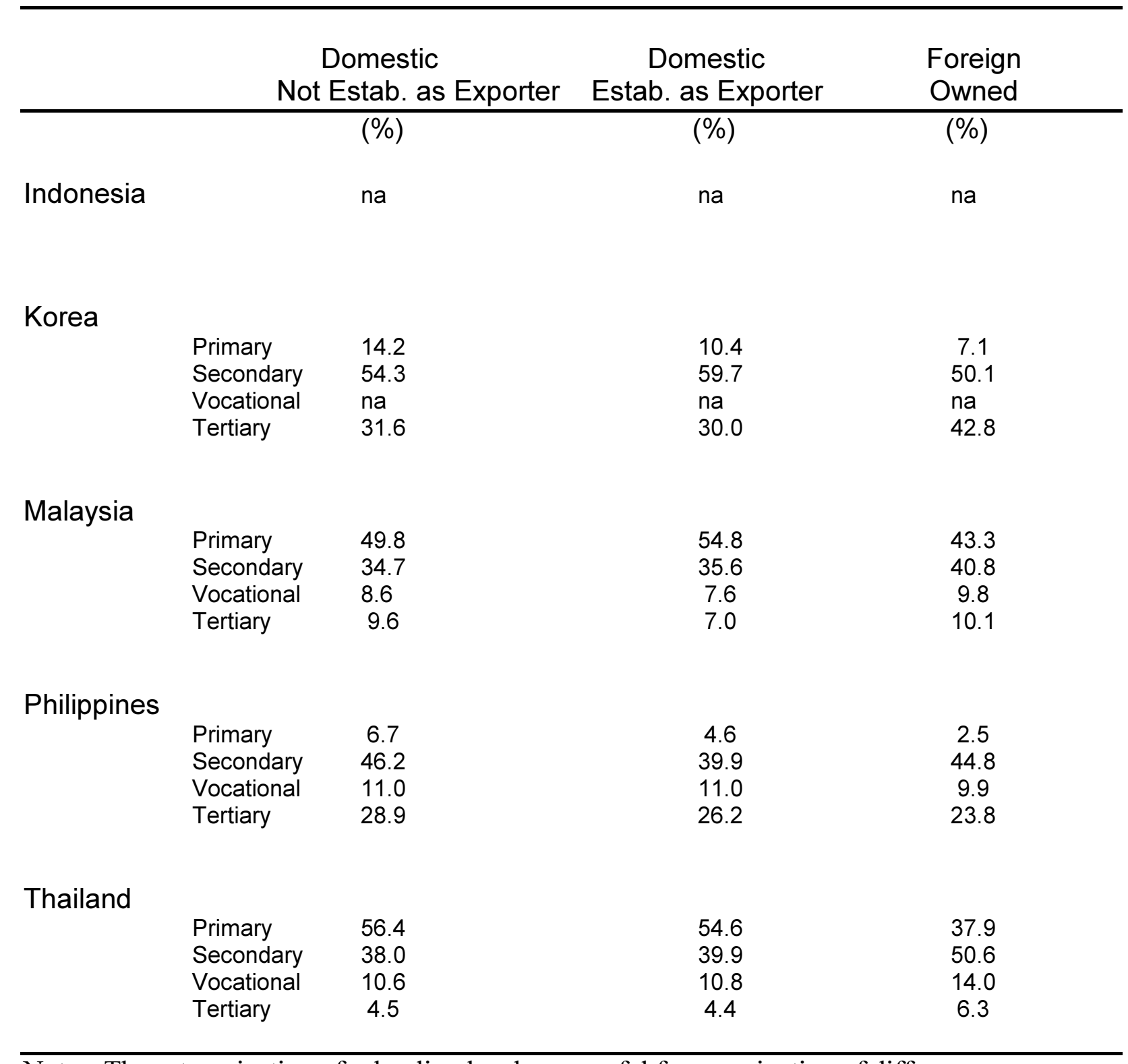

Notes: The categorization of schooling levels are useful for examination of differences across firms within countries, but are not strictly comparable across countries. 


\section{Table 6a}

\section{Regressions with Log of Capital-Labor Ratio as Dependent Variable}

\begin{tabular}{|c|c|c|c|c|c|}
\hline & (1) & (2) & (3) & (4) & (5) \\
\hline & Indonesia & Korea & Malaysia & Philippines & Thailand \\
\hline FDI $^{1}$ & $\begin{array}{c}1.320 \\
(8.53)^{\star *}\end{array}$ & $\begin{array}{c}0.279 \\
(4.64)^{\star *}\end{array}$ & $\begin{array}{c}0.679 \\
(4.26)^{\star *}\end{array}$ & $\begin{array}{c}0.569 \\
(4.41)^{\star *}\end{array}$ & $\begin{array}{c}0.861 \\
(7.26)^{\star *}\end{array}$ \\
\hline Domestic Exporter ${ }^{2}$ & $\begin{array}{c}0.540 \\
(5.01)^{\star *}\end{array}$ & $\begin{array}{c}0.153 \\
(3.28)^{\star *}\end{array}$ & $\begin{array}{c}0.299 \\
(2.44)^{*}\end{array}$ & $\begin{array}{c}0.308 \\
(2.48)^{*}\end{array}$ & $\begin{array}{c}0.477 \\
(4.88)^{\star *}\end{array}$ \\
\hline Capacity Utilization & $\begin{array}{l}-0.001 \\
(0.68)\end{array}$ & $\begin{array}{l}0.001 \\
(0.76)\end{array}$ & $\begin{array}{l}-0.001 \\
(0.42)\end{array}$ & $\begin{array}{l}-0.006 \\
(2.40)^{*}\end{array}$ & $\begin{array}{l}-0.004 \\
(2.04)^{*}\end{array}$ \\
\hline $\mathrm{Age}^{3}$ & $\begin{array}{l}0.009 \\
(0.78)\end{array}$ & $\begin{array}{l}0.007 \\
(1.63)\end{array}$ & $\begin{array}{l}0.008 \\
(0.66)\end{array}$ & $\begin{array}{l}0.015 \\
(1.66)\end{array}$ & $\begin{array}{l}0.020 \\
(1.26)\end{array}$ \\
\hline $\mathrm{Age}^{\wedge} 2$ & $\begin{array}{l}-0.000 \\
(0.59)\end{array}$ & $\begin{array}{l}0.000 \\
(1.04)\end{array}$ & $\begin{array}{l}0.000 \\
(0.40)\end{array}$ & $\begin{array}{l}-0.000 \\
(0.59)\end{array}$ & $\begin{array}{c}-0.000 \\
(0.16)\end{array}$ \\
\hline Large & $\begin{array}{c}0.379 \\
(3.39)^{\star *}\end{array}$ & $\begin{array}{c}0.373 \\
(8.92)^{\star *}\end{array}$ & $\begin{array}{l}-0.071 \\
(0.60)\end{array}$ & $\begin{array}{c}0.425 \\
(3.93)^{\star *}\end{array}$ & $\begin{array}{c}0.484 \\
(5.13)^{\star *}\end{array}$ \\
\hline Observations & 806 & 1615 & 1141 & 780 & 766 \\
\hline R-squared & 0.25 & 0.18 & 0.12 & 0.17 & 0.30 \\
\hline
\end{tabular}

Sector dummies and year dummies were included, but not reported.

Robust t-statistics in parentheses; * significant at $5 \%$; ** significant at $1 \%$

Note: $\quad 1$ Dummy variable: $1=$ firm has at least $10 \%$ of equity foreign owned, $0=$ otherwise.

${ }^{2}$ Dummy variable: $1=$ exporter with less than $10 \%$ of equity foreign owned; $0=$ otherwise.

${ }^{3}$ Number of years since establishment

Source: World Bank, Asian Corporate Crisis \& Recovery Firm-Level Survey 1999 


\section{Table 6b}

\section{Regressions with Fraction of Assets in Recent Vintage of Capital as Dependent Variable}

\begin{tabular}{|c|c|c|c|c|c|}
\hline & $\begin{array}{c}(1) \\
\% \text { of } \\
\text { equipment } \\
<4 \mathrm{yr} \\
\text { Indonesia } \\
\end{array}$ & $\begin{array}{c}(2) \\
\% \text { of } \\
\text { equipment } \\
<4 \mathrm{yr} \\
\text { Korea } \\
\end{array}$ & $\begin{array}{c}(3) \\
\% \text { of } \\
\text { equipment } \\
<4 \mathrm{yr} \\
\text { Malaysia } \\
\end{array}$ & $\begin{array}{c}\text { (4) } \\
\% \text { of } \\
\text { equipment } \\
<4 \mathrm{yr} \\
\text { Philippines }\end{array}$ & $\begin{array}{c}\text { (5) } \\
\% \text { of } \\
\text { equipment } \\
<4 \mathrm{yr} \\
\text { Thailand }\end{array}$ \\
\hline $\mathrm{FDI}^{1}$ & $\begin{array}{l}1.381 \\
(0.36)\end{array}$ & $\begin{array}{l}3.152 \\
(1.32)\end{array}$ & $\begin{array}{l}4.494 \\
(1.86)\end{array}$ & $\begin{array}{l}15.684 \\
(5.21)^{\star \star}\end{array}$ & $\begin{array}{l}-2.939 \\
(1.09)\end{array}$ \\
\hline $\begin{array}{l}\text { Domestic, Established } \\
\text { Exporter }^{2}\end{array}$ & $\begin{array}{l}-5.542 \\
(1.57)\end{array}$ & $\begin{array}{l}0.571 \\
(0.24)\end{array}$ & $\begin{array}{l}1.366 \\
(0.45)\end{array}$ & $\begin{array}{l}2.739 \\
(0.63)\end{array}$ & $\begin{array}{c}9.197 \\
(2.74)^{\star *}\end{array}$ \\
\hline $\begin{array}{l}\text { Domestic, Became } \\
\text { Exporter }^{3}\end{array}$ & $\begin{array}{r}-1.162 \\
(0.44)\end{array}$ & $\begin{array}{l}2.889 \\
(1.57)\end{array}$ & $\begin{array}{c}5.498 \\
(2.72)^{* *}\end{array}$ & $\begin{array}{c}8.193 \\
(2.69)^{* *}\end{array}$ & $\begin{array}{l}5.886 \\
(2.45)^{*}\end{array}$ \\
\hline Capacity Utilization & $\begin{array}{l}0.086 \\
(1.80)\end{array}$ & $\begin{array}{l}-0.016 \\
(0.35)\end{array}$ & $\begin{array}{c}0.190 \\
(5.12)^{\star *}\end{array}$ & $\begin{array}{l}-0.066 \\
(1.01)\end{array}$ & $\begin{array}{l}0.046 \\
(0.98)\end{array}$ \\
\hline Size Dummy ${ }^{4}$ & $\begin{array}{r}-1.935 \\
(0.73)\end{array}$ & $\begin{array}{l}1.311 \\
(0.84)\end{array}$ & $\begin{array}{l}8.400 \\
(4.39)^{* *}\end{array}$ & $\begin{array}{c}4.868 \\
(1.98)^{*}\end{array}$ & $\begin{array}{c}6.603 \\
(2.97)^{* *}\end{array}$ \\
\hline $\mathrm{Age}^{5}$ & $\begin{array}{l}-1.186 \\
(4.18)^{* *}\end{array}$ & $\begin{array}{l}-1.653 \\
(8.17)^{* *}\end{array}$ & $\begin{array}{l}-0.759 \\
(3.37)^{\star *}\end{array}$ & $\begin{array}{l}-1.068 \\
(4.96)^{\star *}\end{array}$ & $\begin{array}{l}-1.743 \\
(4.03)^{* *}\end{array}$ \\
\hline $\mathrm{Age}^{\wedge} 2$ & $\begin{array}{c}0.012 \\
(3.01)^{* *}\end{array}$ & $\begin{array}{l}0.021 \\
(6.23)^{* *}\end{array}$ & $\begin{array}{l}0.008 \\
(2.44)^{*}\end{array}$ & $\begin{array}{c}0.011 \\
(3.88)^{* *}\end{array}$ & $\begin{array}{c}0.025 \\
(2.85)^{* *}\end{array}$ \\
\hline Observations & 763 & 1541 & 1122 & 710 & 737 \\
\hline R-squared & 0.08 & 0.08 & 0.09 & 0.17 & 0.13 \\
\hline
\end{tabular}

Sector dummies and year dummies were included, but not reported.

Robust t-statistics in parentheses; * significant at $5 \%$; ${ }^{* *}$ significant at $1 \%$

Note: $\quad{ }^{1}$ Dummy variable: $1=$ firm has at least $10 \%$ of equity foreign owned, $0=$ otherwise.

2 Dummy variable: $1=$ firm with less than $10 \%$ of equity foreign owned and that started exporting within the first year of establishment; currently is exporter. $0=$ otherwise.

${ }^{3}$ Dummy variable: $1=$ firm with less than $10 \%$ of equity foreign owned and that started exporting sometime after the first year of establishment; currently is exporter. $0=0$ otherwise.

${ }^{4}$ Dummy variable: $1=$ firm with 150 or more employees; $0=$ otherwise.

${ }^{5}$ Number of years since establishment.

Source: World Bank, Asian Corporate Crisis \& Recovery Firm-Level Survey 1999 


\section{TABLE 7}

\section{Characteristics of Firms by Export and Ownership}

\begin{tabular}{|c|c|c|c|c|c|c|c|c|}
\hline \multicolumn{5}{|c|}{ TEXTILES } & \multicolumn{4}{|c|}{ ELECTRONICS } \\
\hline & FDI & $\begin{array}{l}\text { Estab } \\
\text { Export }\end{array}$ & $\begin{array}{l}\text { Becme } \\
\text { Export }\end{array}$ & $\begin{array}{l}\text { Domestic } \\
\text { No Exp. }\end{array}$ & FDI & $\begin{array}{l}\text { Estab } \\
\text { Export }\end{array}$ & $\begin{array}{l}\text { Becme } \\
\text { Export }\end{array}$ & $\begin{array}{c}\text { Domestic } \\
\text { No Exp. }\end{array}$ \\
\hline \multicolumn{9}{|c|}{ Median Employment } \\
\hline Indonesia & 711 & 317 & 589 & 85 & 739 & 442 & 213 & 55 \\
\hline Korea & 132 & 101 & 120 & 80 & 239 & 79 & 104 & 89 \\
\hline Malaysia & 187 & 158 & 133 & 17 & 352 & 76 & 181 & 156 \\
\hline Philippines & 212 & 57 & 112 & 51 & 345 & 218 & 425 & 47 \\
\hline Thailand & 138 & 250 & 153 & 46 & 392 & 245 & 83 & 55 \\
\hline
\end{tabular}

Median Capital per Worker

$\begin{array}{lrrrrrrrr}\text { Indonesia } & 27.64 & 5.98 & 17.25 & 3.57 & 29.33 & 43.07 & 10.06 & 11.11 \\ \text { Korea } & 117.75 & 112.14 & 149.04 & 75.57 & 141.95 & 111.11 & 97.2 & 109.83 \\ \text { Malaysia } & 45.23 & 18.30 & 31.85 & 9.74 & 25.54 & 36.95 & 52.32 & 7.01 \\ \text { Philippines } & 10.02 & 8.09 & 23.68 & 16.30 & 17.51 & 8.48 & 9.93 & 12.24 \\ \text { Thailand } & 36.66 & 26.14 & 18.04 & 12.61 & 39.08 & 3.23 & 21.51 & 9.83\end{array}$

Share of Firms with Outside Auditors

$\begin{array}{lllllllll}\text { Indonesia } & 0.69 & 0.33 & 0.56 & 0.25 & 0.89 & 0.80 & 0.64 & 0.28 \\ \text { Korea } & 0.73 & 0.62 & 0.62 & 0.52 & 0.91 & 0.59 & 0.68 & 0.71 \\ \text { Malaysia } & 0.80 & 0.73 & 0.77 & 0.12 & 0.67 & 0.25 & 0.80 & 0.30 \\ \text { Philippines } & 0.97 & 0.50 & 0.90 & 0.71 & 0.97 & 0.82 & 0.88 & 0.81 \\ \text { Thailand } & 0.48 & 0.50 & 0.61 & 0.27 & 0.51 & 0.51 & 0.57 & 0.27\end{array}$

Share of Firms with Formal Training Programs

$\begin{array}{lllllllll}\text { Indonesia } & 0.58 & 0.67 & 0.32 & 0.09 & 0.58 & 0.60 & 0.58 & 0.15 \\ \text { Korea } & 0.50 & 0.27 & 0.18 & 0.14 & 0.61 & 0.37 & 0.51 & 0.43 \\ \text { Malaysia } & 0.30 & 0.36 & 0.31 & 0.04 & 0.56 & 0.50 & 0.40 & 0.40 \\ \text { Philippines } & 0.47 & 0.50 & 0.43 & 0.33 & 0.73 & 0.82 & 0.50 & 0.45 \\ \text { Thailand } & 0.46 & 0.50 & 0.26 & 0.17 & 0.63 & 0.30 & 0.42 & 0.20\end{array}$

Share of Firms Using Foreign Technology

$\begin{array}{lllllllll}\text { Indonesia } & 0.80 & 0.33 & 0.61 & 0.14 & 0.73 & 0.60 & 0.36 & 0.33 \\ \text { Korea } & 0.55 & 0.06 & 0.08 & 0.04 & 0.44 & 0.21 & 0.09 & 0.14 \\ \text { Malaysia } & 0.67 & 0.18 & 0.54 & 0.08 & 0.72 & 0.50 & 0.25 & 0.10 \\ \text { Philippines } & 0.39 & 0.50 & 0.50 & 0.21 & 0.65 & 0.50 & 0.63 & 0.23 \\ \text { Thailand } & 0.61 & 0.67 & 0.46 & 0.18 & 0.79 & 0.38 & 0.23 & 0.25\end{array}$

Source: World Bank, Asian Corporate Crisis \& Recovery Firm-Level Survey 1999 


\section{Table 8a}

\section{Regressions of Total Factor Productivity on Firm Characteristics and Practices: TFP Measures Obtained from Series Estimator}

\begin{tabular}{|c|c|c|c|c|c|}
\hline & $\begin{array}{c}(1) \\
\text { tfp_lps }\end{array}$ & $\begin{array}{c}(2) \\
\text { tfp_lps }\end{array}$ & $\begin{array}{c}(3) \\
\text { tfp_lps }\end{array}$ & $\begin{array}{c}(4) \\
\text { tfp_Ips }\end{array}$ & $\begin{array}{c}(5) \\
\text { tfp_lps }\end{array}$ \\
\hline & Indonesia & Korea & Malaysia & Philippines & Thailand \\
\hline \multirow[t]{2}{*}{ Domestic, Established as Exporter ${ }^{1}$} & 0.203 & -0.007 & 0.224 & 0.253 & 0.156 \\
\hline & $(3.12)^{\star *}$ & $(0.17)$ & $(2.26)^{*}$ & $(3.44)^{\star \star}$ & $(2.58)^{*}$ \\
\hline \multirow[t]{2}{*}{ Domestic, Became Exporter ${ }^{2}$} & 0.041 & 0.004 & 0.157 & 0.139 & 0.003 \\
\hline & $(0.85)$ & $(0.13)$ & $(2.06)^{*}$ & $(2.77)^{\star *}$ & $(0.07)$ \\
\hline \multirow[t]{2}{*}{ Minority Foreign Ownership ${ }^{3}$} & & 0.057 & 0.023 & 0.127 & 0.017 \\
\hline & & $(1.15)$ & $(0.23)$ & $(2.38)^{*}$ & $(0.41)$ \\
\hline \multirow[t]{2}{*}{ Majority Foreign Ownership ${ }^{4}$} & 0.337 & 0.141 & 0.047 & 0.382 & 0.264 \\
\hline & $(4.90)^{* *}$ & $(3.18)^{* *}$ & $(0.47)$ & $(7.22)^{\star *}$ & $(3.84)^{* *}$ \\
\hline \multirow[t]{2}{*}{ Size Dummy ${ }^{5}$} & 0.150 & 0.010 & 0.034 & -0.003 & 0.051 \\
\hline & $(3.68)^{* *}$ & $(0.39)$ & $(0.49)$ & $(0.08)$ & $(1.43)$ \\
\hline \multirow[t]{2}{*}{ Capital city } & 0.057 & 0.074 & 0.135 & 0.100 & -0.007 \\
\hline & $(1.38)$ & $(3.07)^{* *}$ & $(1.92)$ & $(2.97)^{\star *}$ & $(0.17)$ \\
\hline \multirow[t]{2}{*}{ Audited by outside firm } & 0.171 & 0.076 & 0.085 & -0.055 & -0.054 \\
\hline & $(3.94)^{* *}$ & $(2.80)^{* *}$ & $(1.49)$ & $(0.91)$ & $(1.84)$ \\
\hline \multirow[t]{2}{*}{ Training program } & 0.044 & 0.003 & 0.131 & 0.116 & -0.031 \\
\hline & $(1.07)$ & $(0.14)$ & $(1.90)$ & $(3.48)^{\star *}$ & $(0.91)$ \\
\hline Observations & 846 & 1631 & 980 & 758 & 732 \\
\hline R-squared & 0.27 & 0.40 & 0.32 & 0.55 & 0.28 \\
\hline
\end{tabular}

Sector dummies and year dummies were included, but not reported.

Robust t-statistics in parentheses; * significant at 5\%; ${ }^{* *}$ significant at $1 \%$

Note: ${ }^{1}$ Dummy variable: $1=$ firm with less than $10 \%$ of equity foreign owned and that started exporting within the first year of establishment; currently is exporter. $0=0$ otherwise.

${ }^{2}$ Dummy variable: $1=$ firm with less than $10 \%$ of equity foreign owned and that started exporting sometime after the first year of establishment; currently is exporter. $0=0$ otherwise.

${ }^{3}$ Dummy variable: $1=$ firm with $10 \%$ to $49 \%$ of equity foreign owned; $0=$ otherwise.

${ }_{5}^{4}$ Dummy variable: $1=$ firm with $50 \%$ or more of equity foreign owned.

${ }^{5}$ Dummy variable: $1=$ firm with 150 or more employees; $0=$ otherwise.

Source: World Bank, Asian Corporate Crisis \& Recovery Firm-Level Survey 1999. 


\section{Table 8b}

\section{Regressions of Total Factor Productivity on Firm Characteristics and Practices: TFP Measures Obtained from Value Added}

\begin{tabular}{|c|c|c|c|c|c|}
\hline & $\begin{array}{c}(1) \\
\text { TFP }\end{array}$ & $\begin{array}{l}(2) \\
\text { TFP }\end{array}$ & $\begin{array}{l}(3) \\
\text { TFP }\end{array}$ & $\begin{array}{c}(4) \\
\text { TFP }\end{array}$ & $\begin{array}{c}(5) \\
\text { TFP }\end{array}$ \\
\hline & Indonesia & Korea & Malaysia & Philippines & Thailand \\
\hline \multirow[t]{2}{*}{ Domestic, Established as Exporter ${ }^{1}$} & 0.469 & 0.040 & 0.460 & 0.514 & 0.418 \\
\hline & $(3.71)^{\star *}$ & $(0.81)$ & $(3.55)^{\star *}$ & $(3.56)^{\star *}$ & $(3.08)^{* *}$ \\
\hline \multirow[t]{2}{*}{ Domestic, Became Exporter ${ }^{2}$} & 0.208 & 0.062 & 0.224 & 0.208 & 0.214 \\
\hline & $(2.13)^{*}$ & $(1.73)$ & $(2.08)^{*}$ & $(1.92)$ & $(2.32)^{*}$ \\
\hline \multirow[t]{2}{*}{ Minority Foreign Ownership ${ }^{3}$} & & 0.129 & 0.222 & 0.329 & 0.196 \\
\hline & & $(2.50)^{*}$ & $(1.54)$ & $(2.32)^{*}$ & $(2.20)^{*}$ \\
\hline \multirow[t]{2}{*}{ Majority Foreign Ownership ${ }^{4}$} & 0.602 & 0.260 & 0.115 & 0.916 & 0.575 \\
\hline & $(5.03)^{* *}$ & $(5.46)^{\star *}$ & $(0.84)$ & $(7.24)^{\star *}$ & $(4.23)^{\star *}$ \\
\hline \multirow[t]{2}{*}{ Size Dummy ${ }^{5}$} & 0.164 & -0.022 & -0.092 & 0.162 & 0.126 \\
\hline & $(1.96)$ & $(0.77)$ & $(0.87)$ & $(1.80)$ & $(1.63)$ \\
\hline \multirow[t]{2}{*}{ Capital city } & 0.111 & 0.112 & 0.287 & 0.295 & -0.022 \\
\hline & $(1.25)$ & $(3.96)^{\star *}$ & $(2.77)^{\star *}$ & $(3.74)^{\star *}$ & $(0.26)$ \\
\hline \multirow[t]{2}{*}{ Audited by outside firm } & 0.415 & 0.105 & 0.306 & -0.004 & 0.092 \\
\hline & $(5.03)^{\star \star}$ & $(3.26)^{\star *}$ & $(3.71)^{\star *}$ & $(0.03)$ & $(1.27)$ \\
\hline \multirow[t]{2}{*}{ Training program } & 0.162 & 0.007 & 0.229 & 0.165 & -0.007 \\
\hline & $(2.07)^{\star}$ & $(0.27)$ & $(2.16)^{*}$ & $(2.11)^{*}$ & $(0.09)$ \\
\hline Observations & 846 & 1631 & 1118 & 769 & 736 \\
\hline R-squared & 0.17 & 0.05 & 0.07 & 0.15 & 0.13 \\
\hline
\end{tabular}

Sector dummies and year dummies were included, but not reported.

Robust t-statistics in parentheses; * significant at $5 \%$; ${ }^{* *}$ significant at $1 \%$

Note: ${ }^{1}$ Dummy variable: $1=$ firm with less than $10 \%$ of equity foreign owned and that started exporting within the first year of establishment; currently is exporter. $0=0$ otherwise.

${ }^{2}$ Dummy variable: $1=$ firm with less than $10 \%$ of equity foreign owned and that started exporting sometime after the first year of establishment; currently is exporter. $0=$ otherwise.

${ }^{3}$ Dummy variable: $1=$ firm with $10 \%$ to $49 \%$ of equity foreign owned; $0=$ otherwise.

${ }^{4}$ Dummy variable: $1=$ firm with $50 \%$ or more of equity foreign owned.

${ }^{5}$ Dummy variable: $1=$ firm with 150 or more employees; $0=$ otherwise.

Source: World Bank, Asian Corporate Crisis \& Recovery Firm-Level Survey 1999 


\section{Table 9a \\ Regressions of Total Factor Productivity on Firm Characteristics with Ownership: With TFP Measures Obtained from Series Estimator}

\begin{tabular}{|c|c|c|c|c|c|}
\hline & $\begin{array}{c}(1) \\
\text { tfp_lps }\end{array}$ & $\begin{array}{c}(2) \\
\text { Tfp_Ips }\end{array}$ & $\begin{array}{c}(3) \\
\text { tfp_Ips }\end{array}$ & $\begin{array}{c}(4) \\
\text { tfp_Ips }\end{array}$ & $\begin{array}{c}(5) \\
\text { tfp_Ips }\end{array}$ \\
\hline & Indonesia & Korea & Malaysia & Philippines & Thailand \\
\hline Domestic, Established as Exporter ${ }^{1}$ & $\begin{array}{c}0.221 \\
(3.45)^{\star *}\end{array}$ & $\begin{array}{l}0.003 \\
(0.07)\end{array}$ & $\begin{array}{l}0.119 \\
(1.20)\end{array}$ & $\begin{array}{c}0.271 \\
(3.66)^{\star \star}\end{array}$ & $\begin{array}{c}0.143 \\
(2.21)^{*}\end{array}$ \\
\hline Domestic, Became Exporter ${ }^{2}$ & $\begin{array}{l}0.060 \\
(1.21)\end{array}$ & $\begin{array}{l}0.030 \\
(0.98)\end{array}$ & $\begin{array}{l}0.088 \\
(1.10)\end{array}$ & $\begin{array}{c}0.140 \\
(2.82)^{\star \star}\end{array}$ & $\begin{array}{l}-0.023 \\
(0.60)\end{array}$ \\
\hline Minority Foreign Ownership ${ }^{3}$ & & $\begin{array}{l}0.079 \\
(1.59)\end{array}$ & $\begin{array}{l}-0.048 \\
(0.45)\end{array}$ & $\begin{array}{c}0.116 \\
(2.21)^{*}\end{array}$ & $\begin{array}{l}0.008 \\
(0.20)\end{array}$ \\
\hline Majority Foreign Ownership ${ }^{4}$ & $\begin{array}{c}0.404 \\
(6.26)^{\star \star}\end{array}$ & $\begin{array}{c}0.182 \\
(4.19)^{\star \star}\end{array}$ & $\begin{array}{l}-0.065 \\
(0.65)\end{array}$ & $\begin{array}{c}0.393 \\
(7.52)^{\star \star}\end{array}$ & $\begin{array}{c}0.205 \\
(3.28)^{\star *}\end{array}$ \\
\hline Capital city & $\begin{array}{l}0.048 \\
(1.13)\end{array}$ & $\begin{array}{c}0.070 \\
(2.87)^{\star \star}\end{array}$ & $\begin{array}{c}0.140 \\
(2.04)^{*}\end{array}$ & $\begin{array}{c}0.096 \\
(2.87)^{\star *}\end{array}$ & $\begin{array}{l}0.021 \\
(0.59)\end{array}$ \\
\hline Partnerships & $\begin{array}{l}-0.205 \\
(1.44)\end{array}$ & $\begin{array}{l}0.133 \\
(1.67)\end{array}$ & $\begin{array}{l}-0.073 \\
(0.64)\end{array}$ & $\begin{array}{l}0.081 \\
(0.43)\end{array}$ & $\begin{array}{c}0.213 \\
(3.77)^{\star *}\end{array}$ \\
\hline Cooperatives & & $\begin{array}{l}0.034 \\
(0.51)\end{array}$ & & $\begin{array}{l}0.160 \\
(0.87)\end{array}$ & \\
\hline Limited Liability & $\begin{array}{c}0.121 \\
(2.19)^{*}\end{array}$ & $\begin{array}{l}-0.033 \\
(0.68)\end{array}$ & $\begin{array}{l}0.139 \\
(1.46)\end{array}$ & $\begin{array}{l}0.035 \\
(0.46)\end{array}$ & $\begin{array}{c}0.210 \\
(2.86)^{\star *}\end{array}$ \\
\hline Publicly Listed & $\begin{array}{l}0.114 \\
(1.61)\end{array}$ & $\begin{array}{l}-0.033 \\
(1.12)\end{array}$ & $\begin{array}{l}0.513 \\
(0.95)\end{array}$ & $\begin{array}{l}-0.006 \\
(0.07)\end{array}$ & $\begin{array}{l}0.206 \\
(1.39)\end{array}$ \\
\hline Observations & 846 & 1596 & 980 & 787 & 741 \\
\hline R-squared & 0.26 & 0.39 & 0.33 & 0.55 & 0.30 \\
\hline
\end{tabular}

Sector, size and year dummies were included, but not reported.

Robust t-statistics in parentheses; * significant at $5 \%$; ** significant at $1 \%$

Note: ${ }^{1}$ Dummy variable: $1=$ firm with less than $10 \%$ of equity foreign owned and that started exporting within the first year of establishment; currently is exporter. $0=$ otherwise.

${ }^{2}$ Dummy variable: $1=$ firm with less than $10 \%$ of equity foreign owned and that started exporting sometime after the first year of establishment; currently is exporter. $0=0$ otherwise.

${ }^{3}$ Dummy variable: $1=$ firm with $10 \%$ to $49 \%$ of equity foreign owned; $0=$ otherwise.

${ }^{4}$ Dummy variable: $1=$ firm with $50 \%$ or more of equity foreign owned.

Source: World Bank, Asian Corporate Crisis \& Recovery Firm-Level Survey 1999 


\section{Table 9b}

\section{Regressions of Total Factor Productivity on Firm Characteristics with Ownership: With TFP Measures Derived from OLS Value Added Specification}

\begin{tabular}{|c|c|c|c|c|c|}
\hline & (1) & (2) & (3) & (4) & (5) \\
\hline & TFP & TFP & TFP & TFP & TFP \\
\hline & Indonesia & Korea & Malaysia & Philippines & Thailand \\
\hline \multirow[t]{2}{*}{ Domestic, Established as Exporter ${ }^{1}$} & 0.537 & 0.058 & 0.312 & 0.584 & 0.372 \\
\hline & $(4.22)^{\star *}$ & $(1.16)$ & $(2.20)^{*}$ & $(4.03)^{* *}$ & $(2.52)^{*}$ \\
\hline \multirow[t]{2}{*}{ Domestic, Became Exporter ${ }^{2}$} & 0.278 & 0.094 & 0.168 & 0.245 & 0.152 \\
\hline & $(2.80)^{\star \star}$ & $(2.59)^{\star \star}$ & $(1.40)$ & $(2.25)^{*}$ & $(1.66)$ \\
\hline \multirow[t]{2}{*}{ Minority Foreign Ownership ${ }^{3}$} & & 0.177 & 0.169 & 0.343 & 0.157 \\
\hline & & $(3.40)^{\star \star}$ & $(1.08)$ & $(2.38)^{*}$ & $(1.75)$ \\
\hline \multirow[t]{2}{*}{ Majority Foreign Ownership ${ }^{4}$} & 0.798 & 0.306 & 0.019 & 0.948 & 0.451 \\
\hline & $(6.54)^{\star *}$ & $(6.45)^{\star *}$ & $(0.13)$ & $(7.70)^{\star \star}$ & $(3.62)^{* *}$ \\
\hline \multirow[t]{2}{*}{ Capital city } & 0.101 & 0.111 & 0.278 & 0.279 & -0.000 \\
\hline & $(1.10)$ & $(3.83)^{* \star}$ & $(2.73)^{\star *}$ & $(3.60)^{\star \star}$ & $(0.00)$ \\
\hline \multirow[t]{2}{*}{ Partnerships } & -0.331 & 0.047 & 0.132 & -0.108 & 0.357 \\
\hline & $(1.07)$ & $(0.47)$ & $(0.81)$ & $(0.34)$ & $(2.61)^{* *}$ \\
\hline \multirow[t]{2}{*}{ Cooperatives } & & -0.033 & & -0.007 & \\
\hline & & $(0.41)$ & & $(0.01)$ & \\
\hline \multirow[t]{2}{*}{ Limited Liability } & 0.212 & -0.086 & 0.293 & -0.003 & 0.180 \\
\hline & $(1.86)$ & $(1.41)$ & $(2.04)^{\star}$ & $(0.02)$ & $(1.00)$ \\
\hline \multirow[t]{2}{*}{ Publicly Listed } & 0.041 & -0.029 & 0.718 & -0.197 & 0.143 \\
\hline & $(0.29)$ & $(0.85)$ & $(0.78)$ & $(1.10)$ & $(0.51)$ \\
\hline Observations & 846 & 1596 & 1118 & 798 & 745 \\
\hline R-squared & 0.15 & 0.05 & 0.08 & 0.16 & 0.15 \\
\hline
\end{tabular}

Sector, size and year dummies were included, but not reported.

Robust t-statistics in parentheses; * significant at $5 \%$; ** significant at $1 \%$

Note: ${ }^{1}$ Dummy variable: $1=$ firm with less than $10 \%$ of equity foreign owned and that started exporting within the first year of establishment; currently is exporter. $0=$ otherwise.

${ }^{2}$ Dummy variable: $1=$ firm with less than $10 \%$ of equity foreign owned and that which started exporting sometime after the first year of establishment; currently is exporter. $0=0$ otherwise.

${ }^{3}$ Dummy variable: $1=$ firm with $10 \%$ to $49 \%$ of equity foreign owned; $0=0$ otherwise.

${ }^{4}$ Dummy variable: $1=$ firm with $50 \%$ or more of equity foreign owned.

Source: World Bank, Asian Corporate Crisis \& Recovery Firm-Level Survey 1999 
Table 10

The Significance of the Experience of the Founder:

Regressions using TFP Measures from Series Estimator Production Functions

\begin{tabular}{|c|c|c|c|c|c|}
\hline & Indonesia & Korea & Malaysia & Philippines & Thailand \\
\hline & $\log (\mathrm{tfp})$ & $\log (t f p)$ & $\log (\operatorname{tfp})$ & $\log (\mathrm{tfp})$ & $\log (t f p)$ \\
\hline $\begin{array}{l}\text { Prior Experience } \\
\text { Local Firm }\end{array}$ & $\begin{array}{c}0.191 \\
(3.39)^{\star *}\end{array}$ & $\begin{array}{l}-0.013 \\
(0.50) \\
\end{array}$ & $\begin{array}{l}0.160 \\
(2.24)^{*}\end{array}$ & $\begin{array}{c}0.142 \\
(2.78)^{\star *}\end{array}$ & $\begin{array}{c}0.089 \\
(2.59)^{* *}\end{array}$ \\
\hline $\begin{array}{l}\text { Prior Experience } \\
\text { Foreign Firm }\end{array}$ & $\begin{array}{c}0.245 \\
(2.67)^{\star *}\end{array}$ & $\begin{array}{l}0.073 \\
(0.92)\end{array}$ & $\begin{array}{c}-0.335 \\
(3.86)^{\star *}\end{array}$ & $\begin{array}{l}0.091 \\
(1.43)\end{array}$ & $\begin{array}{l}0.093 \\
(1.42)\end{array}$ \\
\hline $\begin{array}{c}\text { Prior Experience } \\
\text { Joint Venture }\end{array}$ & $\begin{array}{c}0.394 \\
(4.65)^{\star \star}\end{array}$ & $\begin{array}{l}-0.066 \\
(0.91)\end{array}$ & $\begin{array}{c}0.258 \\
(2.06)^{*}\end{array}$ & $\begin{array}{c}0.300 \\
(3.52)^{* *}\end{array}$ & $\begin{array}{l}0.134 \\
(2.47)^{*}\end{array}$ \\
\hline $\begin{array}{l}\text { Domestic, Estab. } \\
\text { as Exporter }\end{array}$ & $\begin{array}{c}0.204 \\
(3.13)^{\star *}\end{array}$ & $\begin{array}{l}0.001 \\
(0.02)\end{array}$ & $\begin{array}{l}0.139 \\
(1.47)\end{array}$ & $\begin{array}{l}0.182 \\
(2.42)^{*}\end{array}$ & $\begin{array}{l}0.140 \\
(2.35)^{*}\end{array}$ \\
\hline $\begin{array}{l}\text { Minority Foreign } \\
\text { Ownership }\end{array}$ & & $\begin{array}{l}0.081 \\
(1.90)\end{array}$ & $\begin{array}{l}-0.038 \\
(0.39)\end{array}$ & $\begin{array}{l}0.006 \\
(0.11)\end{array}$ & $\begin{array}{l}-0.009 \\
(0.21)\end{array}$ \\
\hline $\begin{array}{l}\text { Majority Foreign } \\
\text { Ownership }\end{array}$ & $\begin{array}{c}0.289 \\
(3.66)^{\star *}\end{array}$ & $\begin{array}{c}0.144 \\
(3.90)^{\star *}\end{array}$ & $\begin{array}{c}0.272 \\
(2.59)^{\star *}\end{array}$ & $\begin{array}{c}0.301 \\
(4.76)^{\star *}\end{array}$ & $\begin{array}{c}0.200 \\
(2.92)^{* *}\end{array}$ \\
\hline $\begin{array}{l}\text { Medium Size (50- } \\
149)\end{array}$ & $\begin{array}{l}0.085 \\
(1.87) \\
\end{array}$ & $\begin{array}{l}0.014 \\
(0.54)\end{array}$ & $\begin{array}{c}0.344 \\
(5.58)^{\star *}\end{array}$ & $\begin{array}{l}0.037 \\
(0.84) \\
\end{array}$ & $\begin{array}{c}0.104 \\
(2.81)^{\star *}\end{array}$ \\
\hline $\begin{array}{l}\text { Large Size (150 } \\
\text { plus) }\end{array}$ & $\begin{array}{c}0.313 \\
(6.66)^{\star *}\end{array}$ & $\begin{array}{l}0.008 \\
(0.26)\end{array}$ & $\begin{array}{c}0.249 \\
(2.63)^{\star *}\end{array}$ & $\begin{array}{l}0.067 \\
(1.47)\end{array}$ & $\begin{array}{l}0.082 \\
(2.12)^{*}\end{array}$ \\
\hline Capital City & $\begin{array}{l}0.001 \\
(0.03)\end{array}$ & $\begin{array}{c}0.082 \\
(3.11)^{\star *}\end{array}$ & $\begin{array}{c}0.176 \\
(2.64)^{\star \star}\end{array}$ & $\begin{array}{l}0.075 \\
(2.11)^{*}\end{array}$ & $\begin{array}{c}0.65 \\
(1.57)\end{array}$ \\
\hline Observations & 778 & 1526 & 965 & 699 & 676 \\
\hline R-squared & 0.27 & 0.39 & 0.37 & 0.57 & 0.30 \\
\hline
\end{tabular}

Notes: Dummy variables for the sectors, years, and age of firm were included, but are not reported. Robust t-statistics are reported within parentheses: *significant at $5 \%$; and ${ }^{* *}$ significant at $1 \%$. See the notes to Table 4. The dummy variables pertaining to the experience of the founder of the firm pertain To the question $\mathrm{n}$ the survey as to whether he or she had previously worked at a firm in the same industry, and who had owned that firm. The excluded category are small, locally-owned firms that Are located outside of the capital city district and were established as non-exporters by a founder with no experience. 
Figure 1: Coefficient of Variation of Total Factor Productivity

All Industries

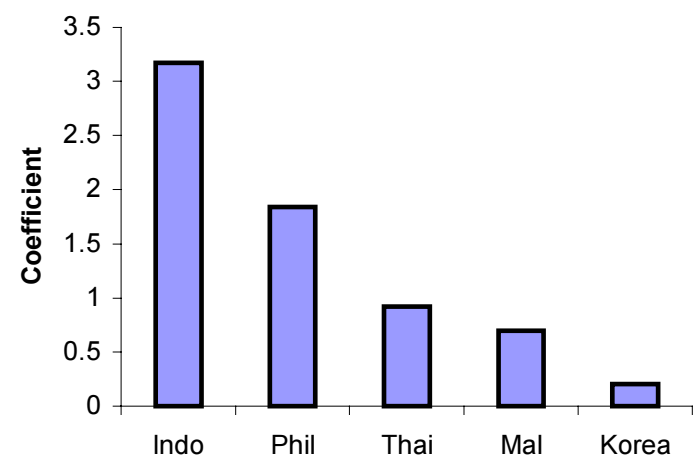

Textiles

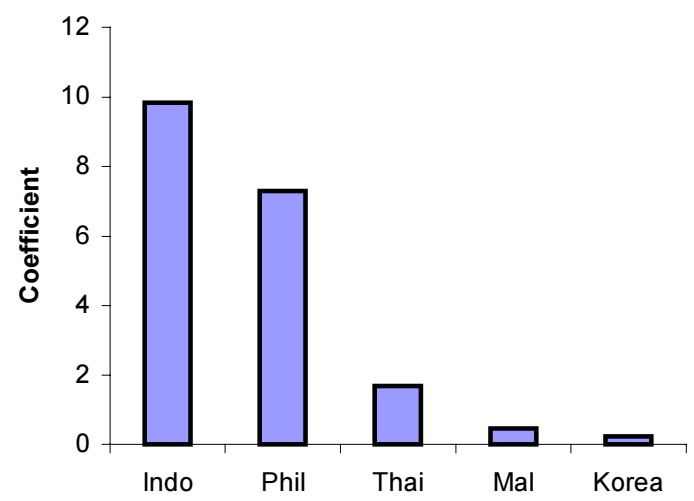

Electronics

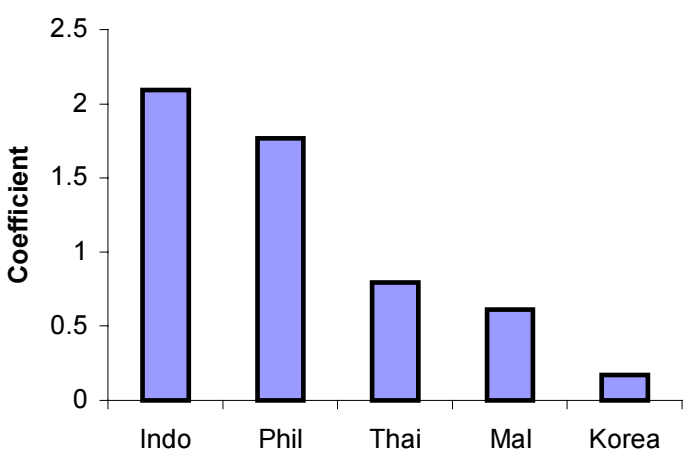

Garments

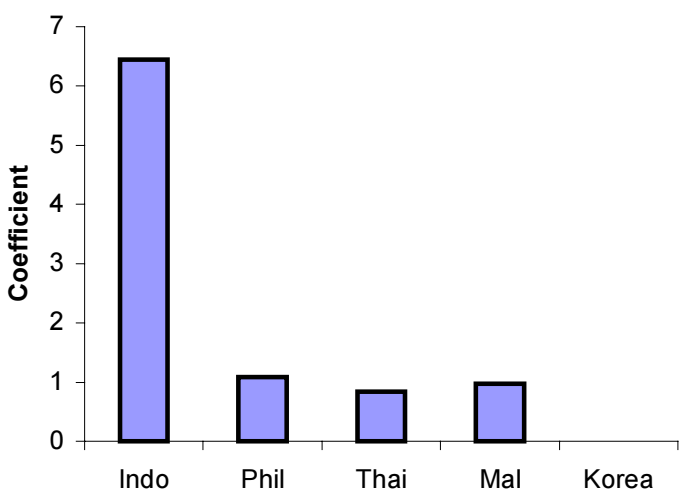

Source: World Bank, Asian Corporate Crisis \& Recovery Firm-Level Survey 1999 
Figure 2

Time between Establishment and First Export

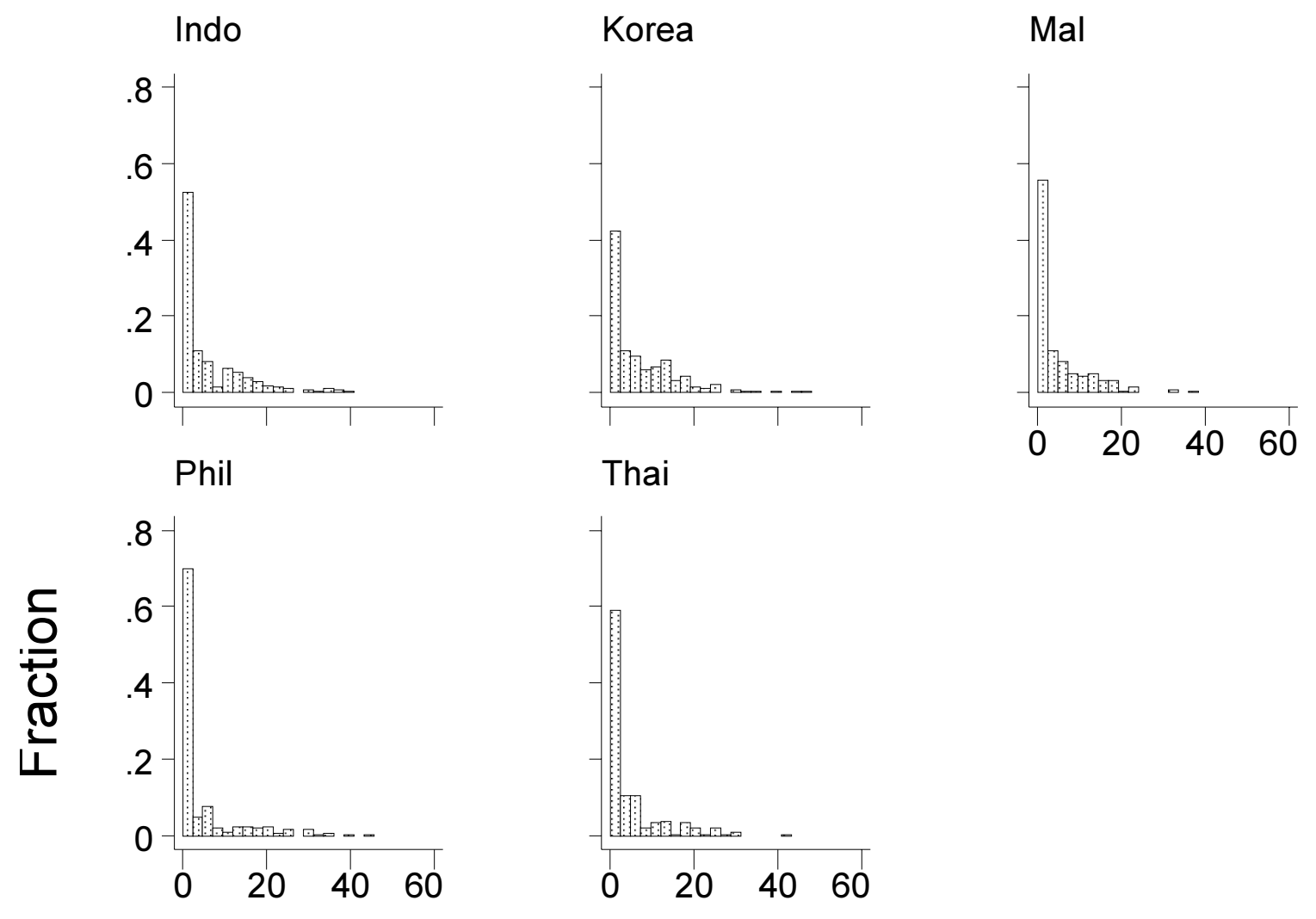

Number of Years Since Establishment 
Figure 3

Share of Export Over Total Sales

Established Exporter

Became Exporter

FDI

Korea
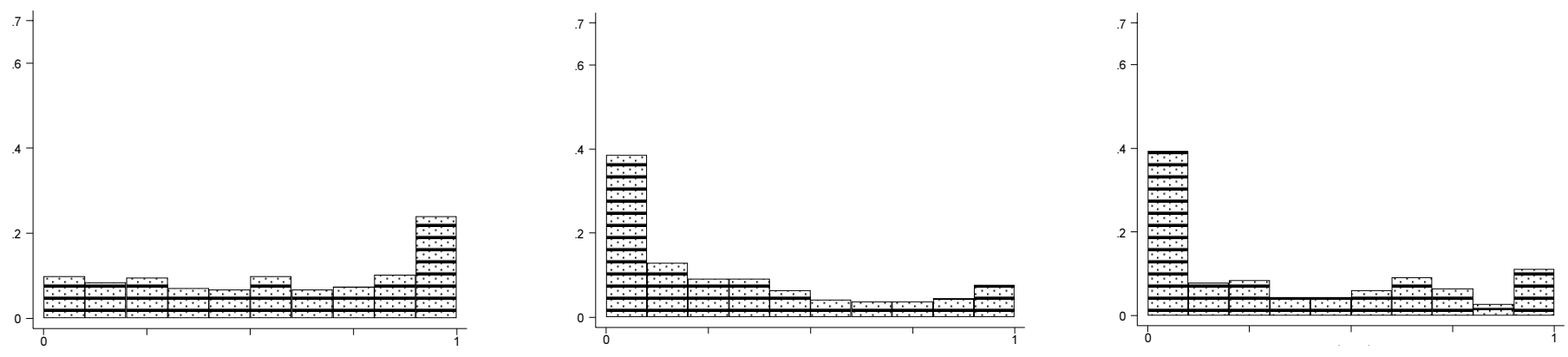

\section{Malaysia}
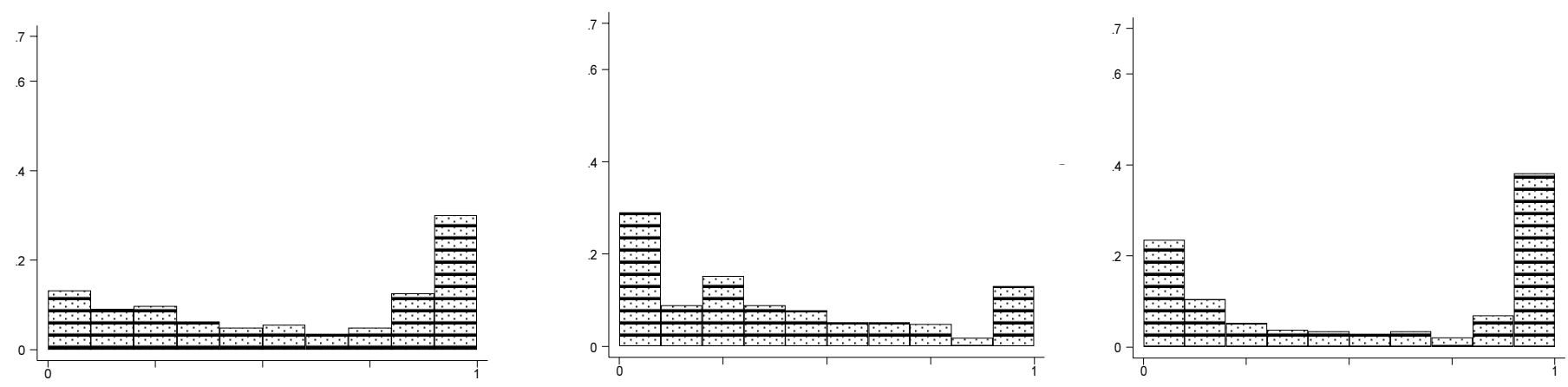

Philippines
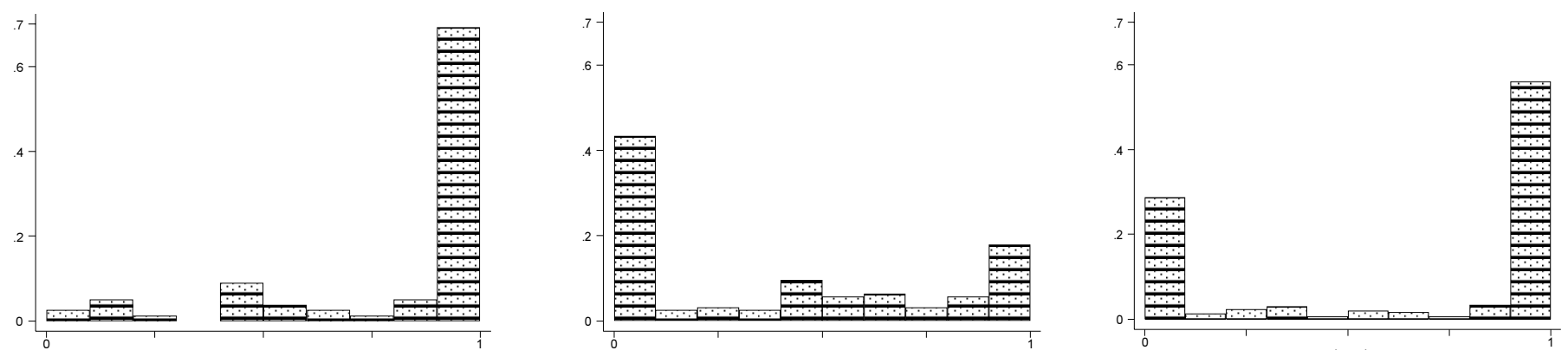

\section{Thailand}
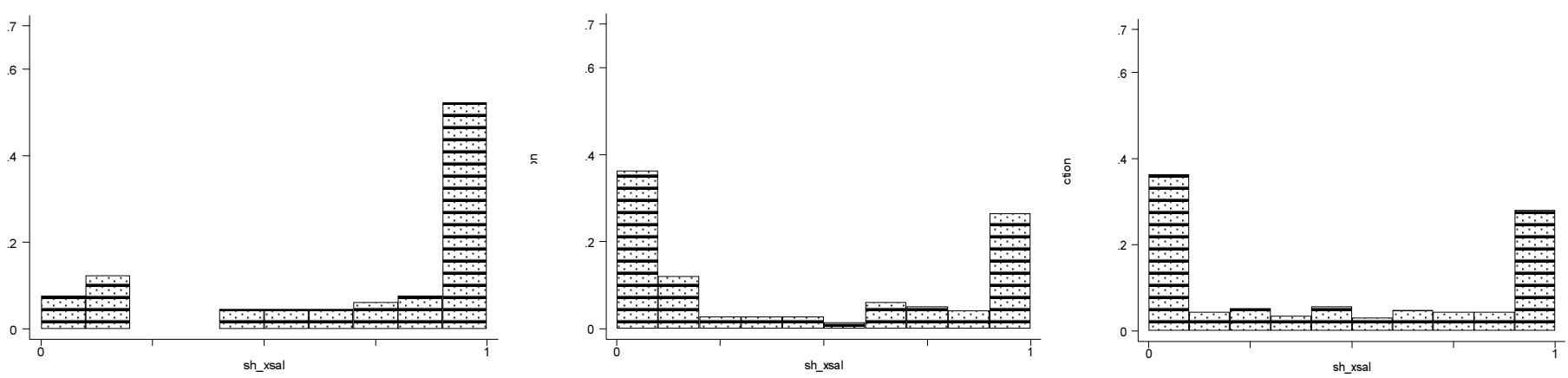

Source: World Bank, Asian Corporate Crisis \& Recovery Firm-Level Survey 1999 


\section{FIGURE 4}

\section{Capital per Worker}

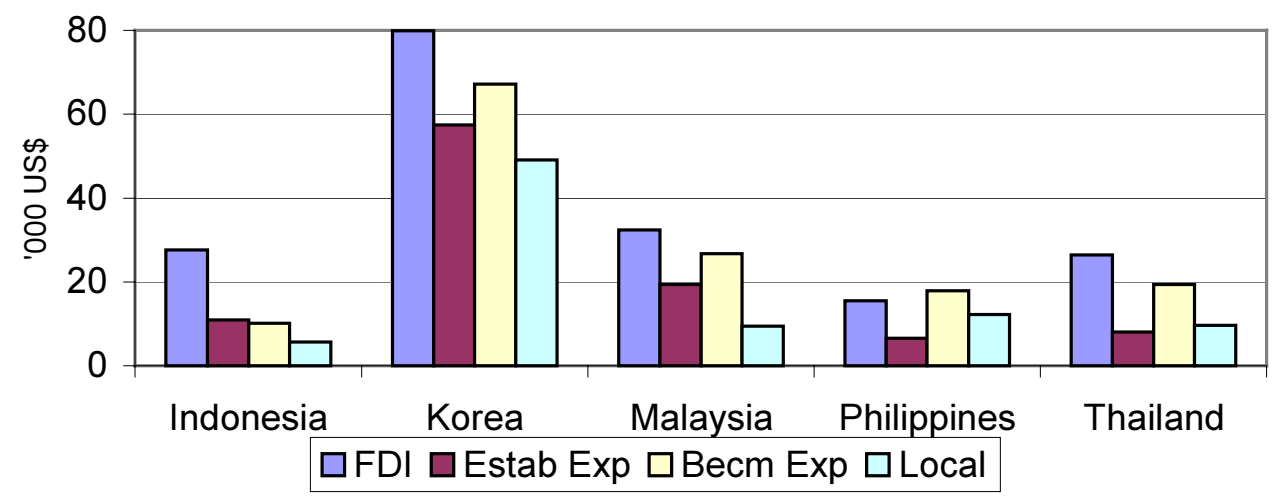

Equipment Less than 4 Years Old

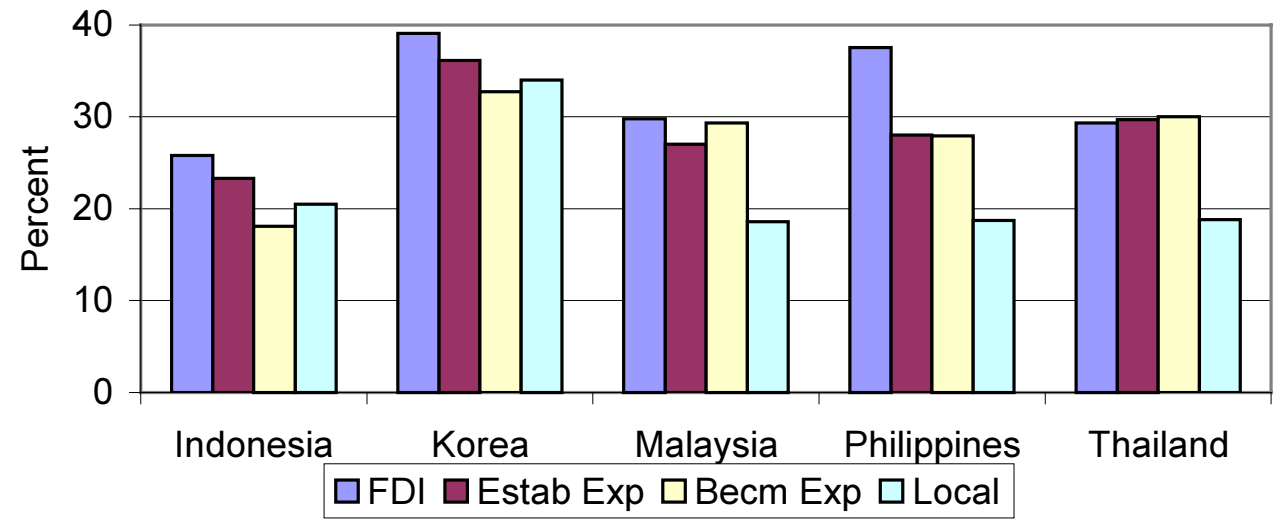

\section{Share of Firms with Outside Auditor}

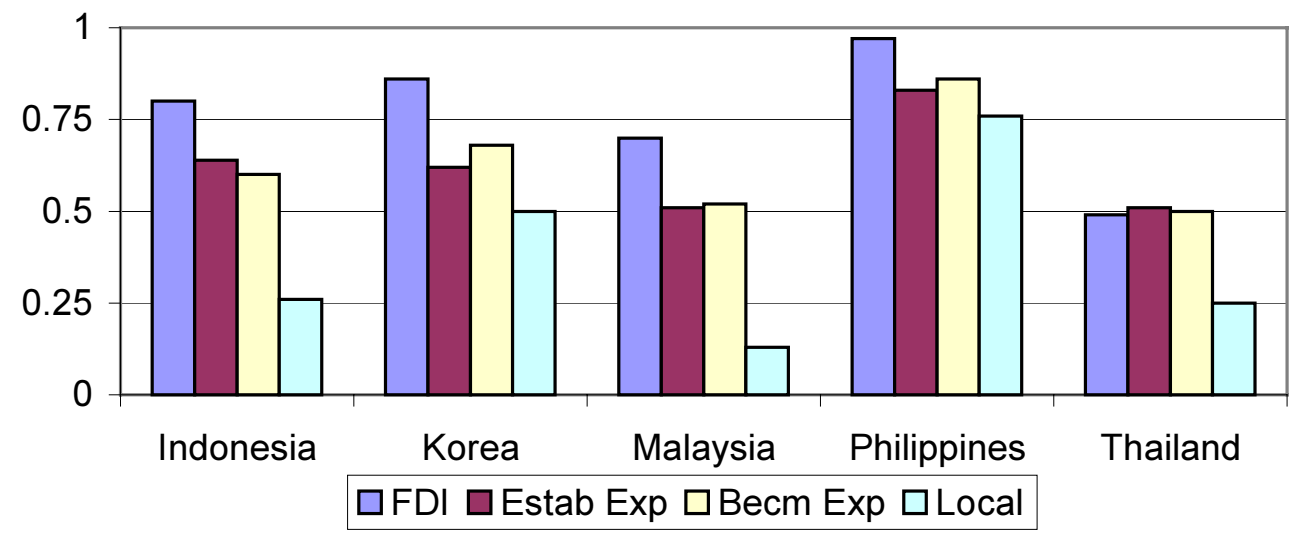




\section{FIGURE 5}

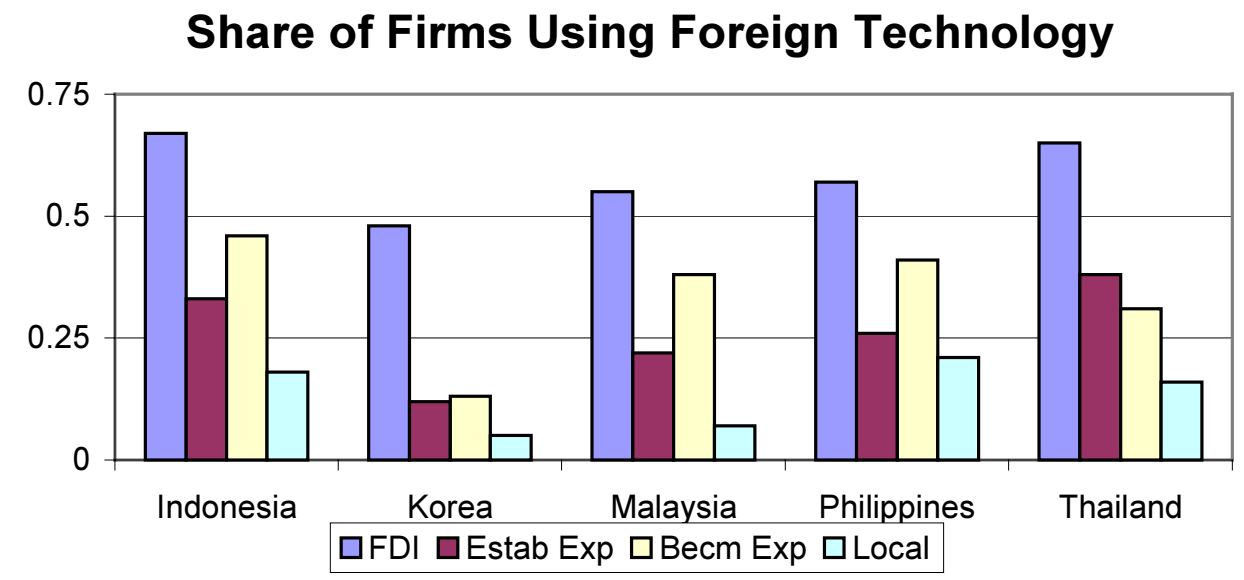

\section{Share of Workers with Primary Education}

Relative to Local Firms' Share

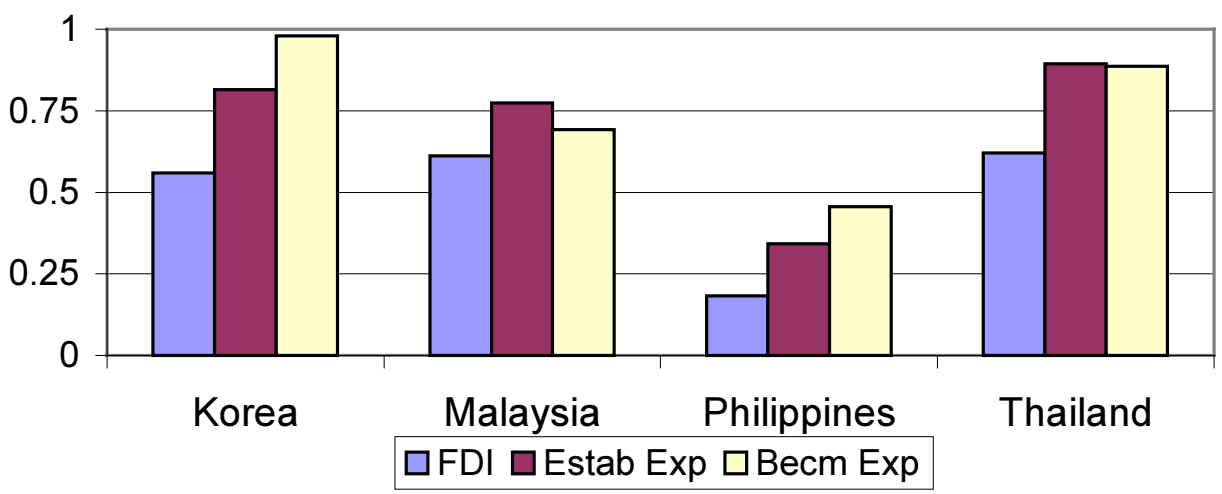

Share of Firms with Formal Training

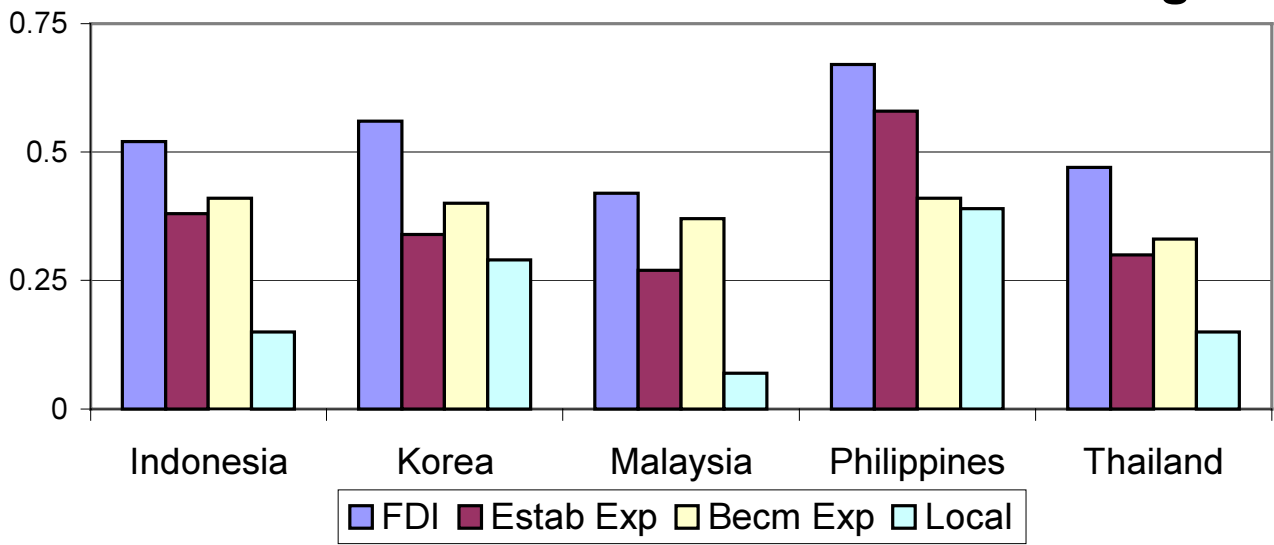

Source: World Bank, Asian Corporate Crisis \& Recovery Firm-Level Survey 1999 